\title{
A 13th century hydraulic ore mill at the mining site of Brandes (Isère), France
}

\author{
Nicolas Minvielle Larousse
}

\begin{abstract}
This paper presents the results of the excavation of an ore grinding watermill brought to light in Sector B 121 of the industrial quarter of the mining town of Brandes (Isère, France). The mill, dated by dendrochronology the 13th century AD, was driven with water channelled from the Font-Morelle spring. The head-race and spillway are examples of the opportunistic reuse of earlier anthropic (canal and mining trench) or natural (faults and karsts) features. The tail-race was not totally excavated. The mill-house (drywall and timber construction) is poorly conserved and the millstone driving mechanisms are difficult to interpret. A series of features suggest the use of a horizontal water wheel driven counterclockwise by a jet of water guided through a flume. A large number of millstone fragments and flakes were studied in a previous article.
\end{abstract}

Keywords: Brandes, mining, ore grinding watermill, horizontal watermill, millstone, dendrochronology

Nicolas Minvielle Larousse, archaeologist and historian, Aix-Marseille University, CNRS, LA3M; 5, Rue du Château de l'Horloge, BP 647, 13094 Aix-en-Provence, France. Ecole Française de Rome, Piazza Navona 62,00186Rome,minvielle.nicolas@gmail.com

\section{Introduction}

The excavation of the 13th-century ore mill presented in this paper was carried out in the framework of a research program focusing on the industrial quarter of the mining town of Brandes (Isère, France). The site, under study since the 1980s, exploited argentiferous veins between the late 11th century and the first half of the 14th century in the Oisans Mountains at an altitude of $1,800 \mathrm{~m}$ (Bailly-Maître et al. 1994).

Grinding is an important stage in the operational sequence of polymetallic production to enrich the ore (lead, copper, silver). It takes place between the phases of mining and reduction and is intended to separate the impurities from the gangue. In Roman times, although there is evidence of grinding ore with rotary hand querns (Pulou et al. 1997), no hydraulic ore mill has been brought to light. Furthermore, only two such installations are known for the Middle Ages (Benoît 2014). The first, dated to a 13th-14th century, was excavated at a mining site in the Czech Republic in the 1980s (Kurdnáč 1992). Unfortunately, its study does not offer any details except a photograph of the mill's foundation on posts and a millstone dressed with furrows. The second medieval mill, excavated at Pampailly (Rhône, France) in the 1990s (Benoît 1997), unfortunately remains unpublished. Ore grinding millstones are therefore often the only type of artefact serving to identify these types of mills. Since these artefacts are reported in many medieval mining districts (Benoît et al. 1996; Hrubý 2011; Minvielle Larousse et al. 2011b), the mills that drove them must have been widespread.

Since hydraulic ore mills have not, to date, been the subject of a specific publication, this paper is compelled to offer a detailed description of the different mill features brought to light at the different excavation campaigns between 2012 and 2014 (Bailly-Maître and Minvielle Larousse, site report 2014). The analysis begins with a brief 


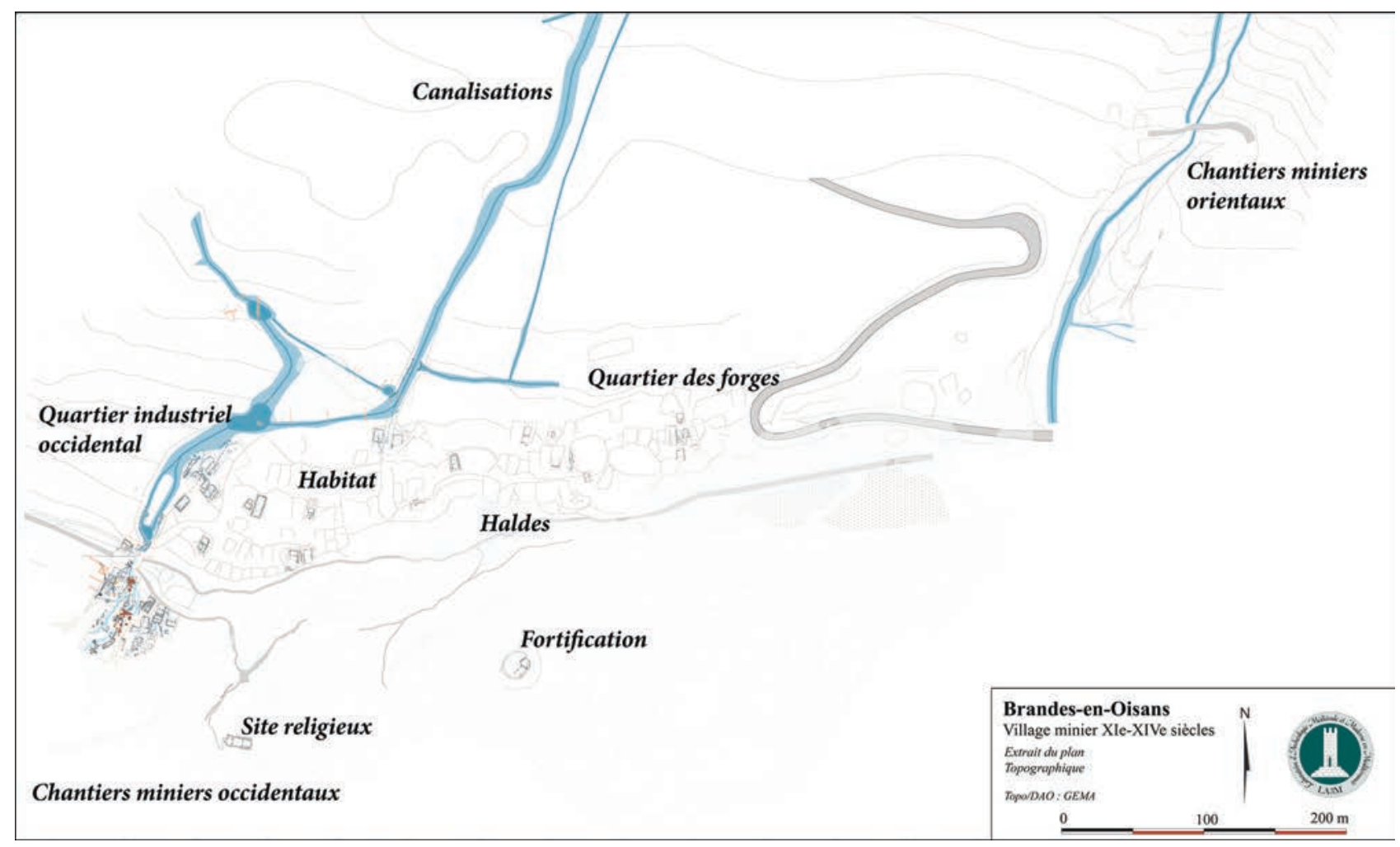

Fig. 1: Map with the location and the main features of the medieval mining settlement of Brandes (Isère, France).

introduction of the geographical, chronological and functional context before describing the installation's main components: the hydraulic system and the mill-house. Hypotheses are then advanced as to how this industrial installation operated and its chronology before offering a series of notions regarding ore mills in general.

\section{Ore grinding in an industrial quarter}

Ore enrichment is a process that took place principally outside of the mine itself. Ore contained in a quartz-barium gangue had to undergo several manual and mechanical treatments, often carried out by means of hydraulic power. Old French texts most often indicate a process divided into three main stages (Bailly-Maître 2000; Mugueta Moreno 2004): 'crushing', 'grinding' and 'washing'. In practice, the separation of the different elements was progressive, implying that all types of ore did not necessarily follow identical processes.

Ore enrichment at Brandes was took place for the most part on the western edge of the settlement (Fig. 1). This industrial quarter, covering an area surpassing a hectare, was arranged around the Font-Morelle spring and a canal (C1) dug by the miners to direct water to the ore grinding and washing workshops. The workshops comprised at least two ore mills and many washing basins. The washing basins were both inside the buildings and outside in the open air. A network of underground conduits serving to steer, evacuate and drain water was spread throughout the area. Two large spoil heaps were downhill. Work related artefacts recovered in the area included mortars, pounders, millstones and a few iron objects (Bailly-Maitre 2002a). Artefacts reflecting the miner's everyday life are also disseminated throughout the area, in particular in the rubbish dumps and in a domestic or administrative building. These artefacts include pottery, and remains of fauna, fruit, clothes, shoes, and other accessories.

\section{Excavation of Sector B 121}

The excavation of Sector B 121 (870 m2) (Fig. 2) was centred on the Font-Morelle spring toward the centre of the lower sector of the industrial area. Its eastern and western limits had been partially explored in previous archaeological campaigns (1980 to 2011). The exploration of the areas was intended to resolve three major issues: a) the organisation of the hydraulic system, b) confirmation of the presence of an ore grinding mill and c) exploitation of the Font-Morelle spring, the only source of sweet water on the plateau.

A three-year program was initiated in 2012 with fieldwork in the uphill zone, followed in 2013 by exploration of the central zone (the mill) and finalised in 2014 with work in the lower zone. The main results of the excavation are the following:

Font-Morelle is a natural karstic spring located about $30 \mathrm{~m}$ north of the mill fed through a network of cracks and fissures. It has its origin at the Lac 


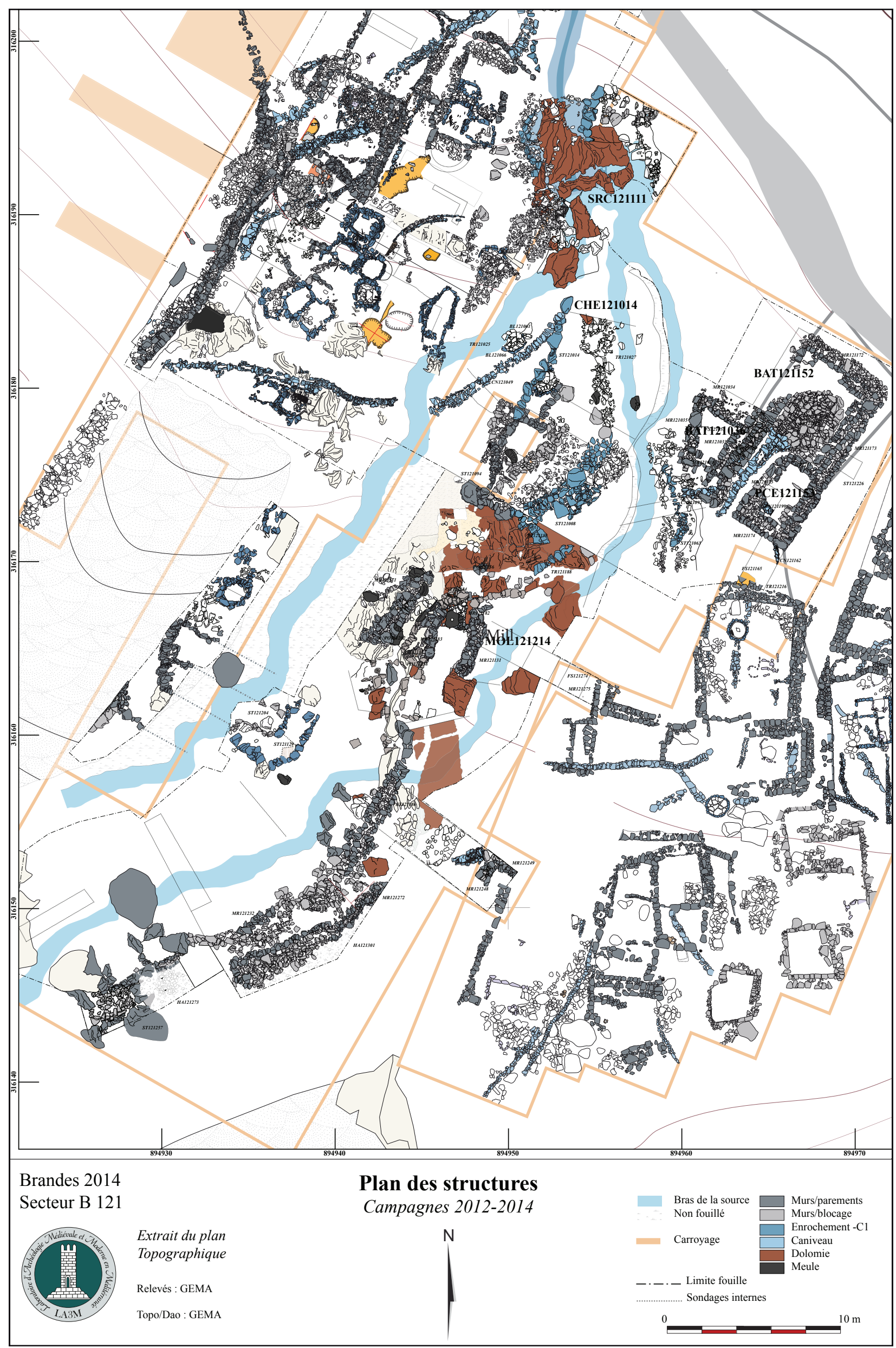

Fig. 2: Detail of the structures of the industrial quarter (Sector B 121) of Brandes (drawing by N. Minvielle Larousse). 
Blanc several kilometres to the north. The water also flowed through the mines and surged on the plateau. No anthropic feature designed to cap, guide or channel the water was observed at the mouth of the Spring.

Downslope from the spring, the upper area of the B 121 sector reveals two major phases of occupation. The first is characterised by the construction of a central terrace with an ore washing basin at is summit. The second is characterised by a heap of stones delimiting the edge of canal $\mathrm{C} 1$.

To the west, the study of the cross section of the spoil heap offered data regarding its content as well as the development of activities in the quarter. Far from being simply a waste dump, the zone served to process the mineral as evidenced by the presence of several washing features some of which contained deposits of sand resulting from grinding.

In addition, a large building with a stone floor unearthed to the east could have served an administrative or a storage function. Further downhill, another two spoil heaps were partially excavated with debris resulting from all of the different phases of the operational sequence of ore grinding and washing that took place at the workshops.

\section{Stratigraphy and chronological phases}

Sector B 121 presents four major chronological phases. The first, preceding the ore mill and probably stretching from the late 11 th to the early 13th century, corresponds to the construction of the terrace located in the uphill zone. The second major phase is associated with the digging of canal $\mathrm{C} 1$, the installation of the ore mill and the mill's life-span from at least $1210 / 1211$ to 1227 . The third phase corresponds to a restructuring of the industrial area, the spoil heaps, and the abandonment of the mill in the second half of the 13th century. The final major phase is the progressive abandonment of the industrial activities. This last phase, initiated in the first half of the 14th century, culminated sometime in the second half of this century.

The stratigraphy observed during the excavation was mainly characterised by the abandonment phase. After the end of its operational life, canal C1 continued to "function" as a torrent until it was gradually backfilled with baryte waste and rocks of different size from the destruction of the different mining features. Although the canal was backfilled, the Font-Morelle spring continued to flow and deposit layers of sand in the area. Finally, when the spring's path was stabilised once again, the area was covered by a thin layer of peat.

The ancient features emerged progressively as each archaeological layer was uncovered. It must be noted that it was at times difficult to distinguish crude dry walling constructions from layers of destruction (Fig. 3). The mill's features appeared under the colluviums directly on the summit of the bedrock (Fig. 4).

The different forms of outcropping of the bedrock is essential to the understanding of the different features of the mill. To the west it surfaces in the form of a hard massive layer of gneiss while to the east it corresponds to a highly weathered Triassic dolomite formation.

Although no pre-medieval structures were identified in this area, it cannot be excluded that anthropic features preceding the mill were erased by erosion. Furthermore, the difference between natural fine hydraulic sands and gravels and human deposits is determined principally by the form of the grains: rounded edges for the natural grains and angular edges for those that are anthropic.

\section{The hydraulic system (Fig. 5) \\ Canal (C1)}

The mill was integrated into the pre-existent industrial hydraulic network. It was raised about $30 \mathrm{~m}$ downhill from the Font-Morelle spring along the course of canal $\mathrm{C} 1$. The earlier phases of the spring, before the mill, did not leave clear traces. Yet what is important for the understanding of the mill is the course of the later contemporary phase of canal $\mathrm{C} 1$ that joined the spring supplying the force to drive the millstone.

It is noteworthy that the stratigraphic sequence of the canal at the level of the mill corresponded to deposits completely different from the backfills both upstream and downstream (Bailly-Maître and Minvielle Larousse, Site Report 2014). This indicates a constant flow of water through the head-race and through the spillway even when a part was directed through the undercroft to drive the wheel. The distinction described below between the two watercourses, the head-race and the spillway, is therefore artificial as they were originally both sections of canal $\mathrm{C} 1$. Yet this study maintains the traditional molinological designations of head-race and spillway for the sake of convenience.

Several trial trenches were sunk to observe the stratigraphy of Canal $\mathrm{C} 1$. The first, $50 \mathrm{~m}$ upstream of the mill, showed the canal to be $1 \mathrm{~m}$ wide and only $5 \mathrm{~cm}$ deep (Bailly-Maître et al., Site Report 2009). Twenty metres downhill, the canal's bed was $1.00 \mathrm{~m}$ to $50 \mathrm{~cm}$ wide and $80 \mathrm{~cm}$ deep (Bailly-Maître and Minvielle Larousse, Site Report 2011). In this area, part of the flow was diverted by two other channels to other workshops. Twelve meters downhill the canal joined the course of the Font-Morelle spring. At the level of the mill itself, the canal measured $1 \mathrm{~m}$ in width and about $1 \mathrm{~m}$ deep, consistent with the previous measurements. Then, at the level of the mill, the spillway became slightly narrower (about $65 \mathrm{~cm}$ wide) and attained a maximum depth of $65 \mathrm{~cm}$.

The canal's bed is too irregular to estimate a rate of water flow, especially as the dimensions correspond to a maximum rate, and the amount of water available would have varied greatly depending on the seasons and the amount of rainfall. In any case, maintenance of the canal, due to all of its irregularities in the faults in the dolomite bedrock, would have been demanding. 


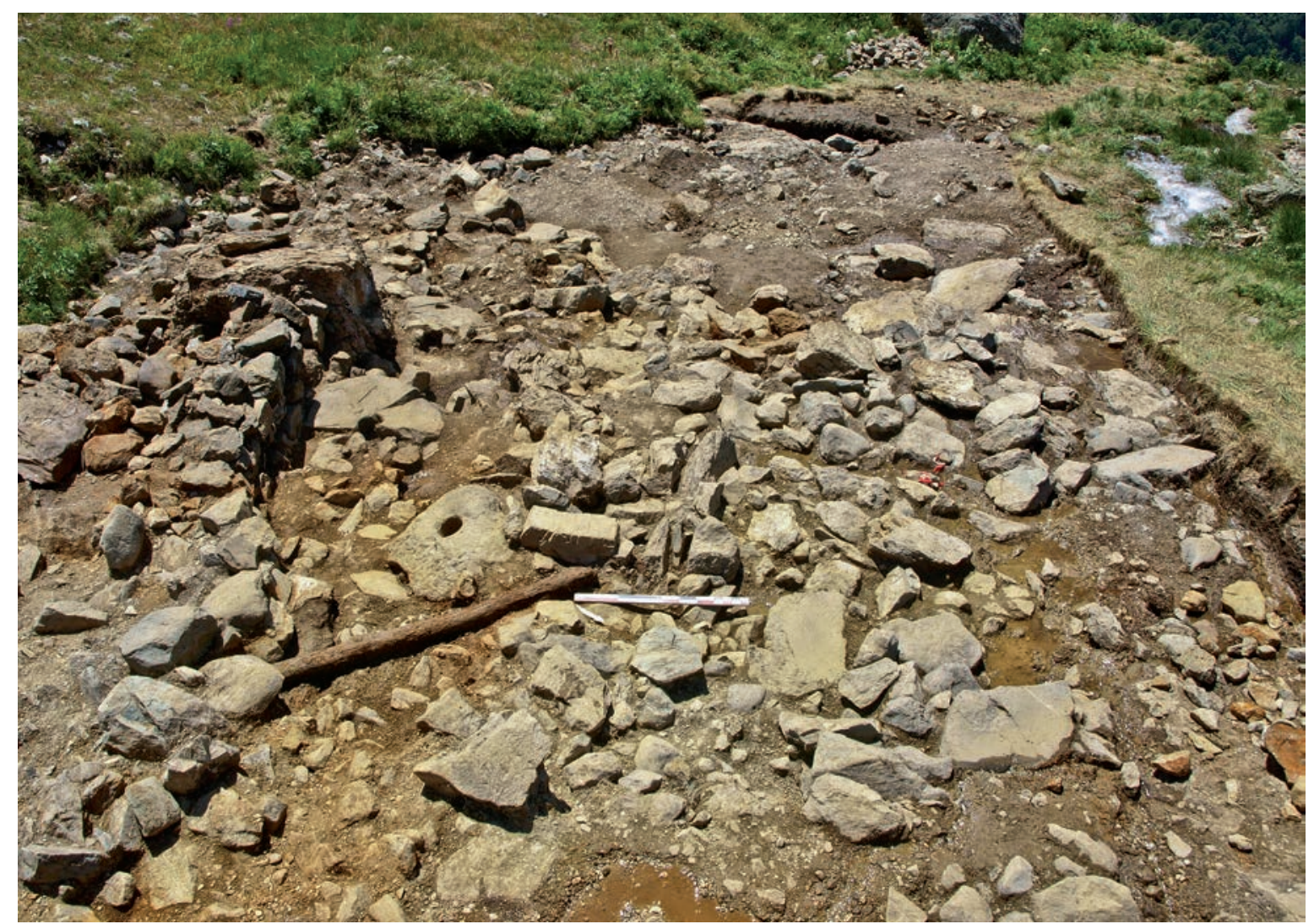

Fig. 3: View from the north-east of the upper layer of demolition of the hydraulic ore mill. A few mill features begin to appear (photograph by N. Minvielle Larousse).

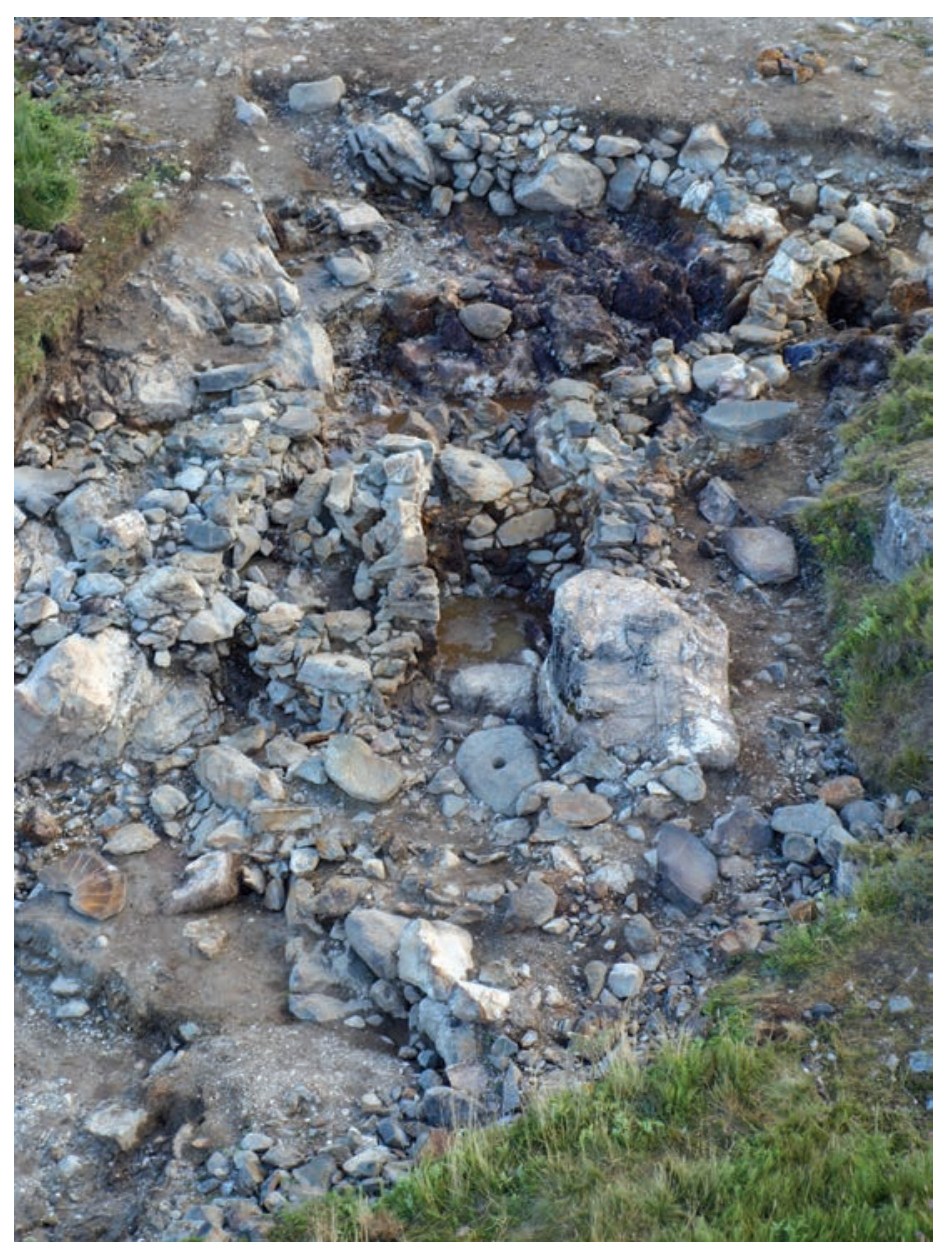

Fig. 4: View of the mill from the south during the intial phase of excavation when its characteristic features began to appear (photograph by N. Minvielle Larousse). 


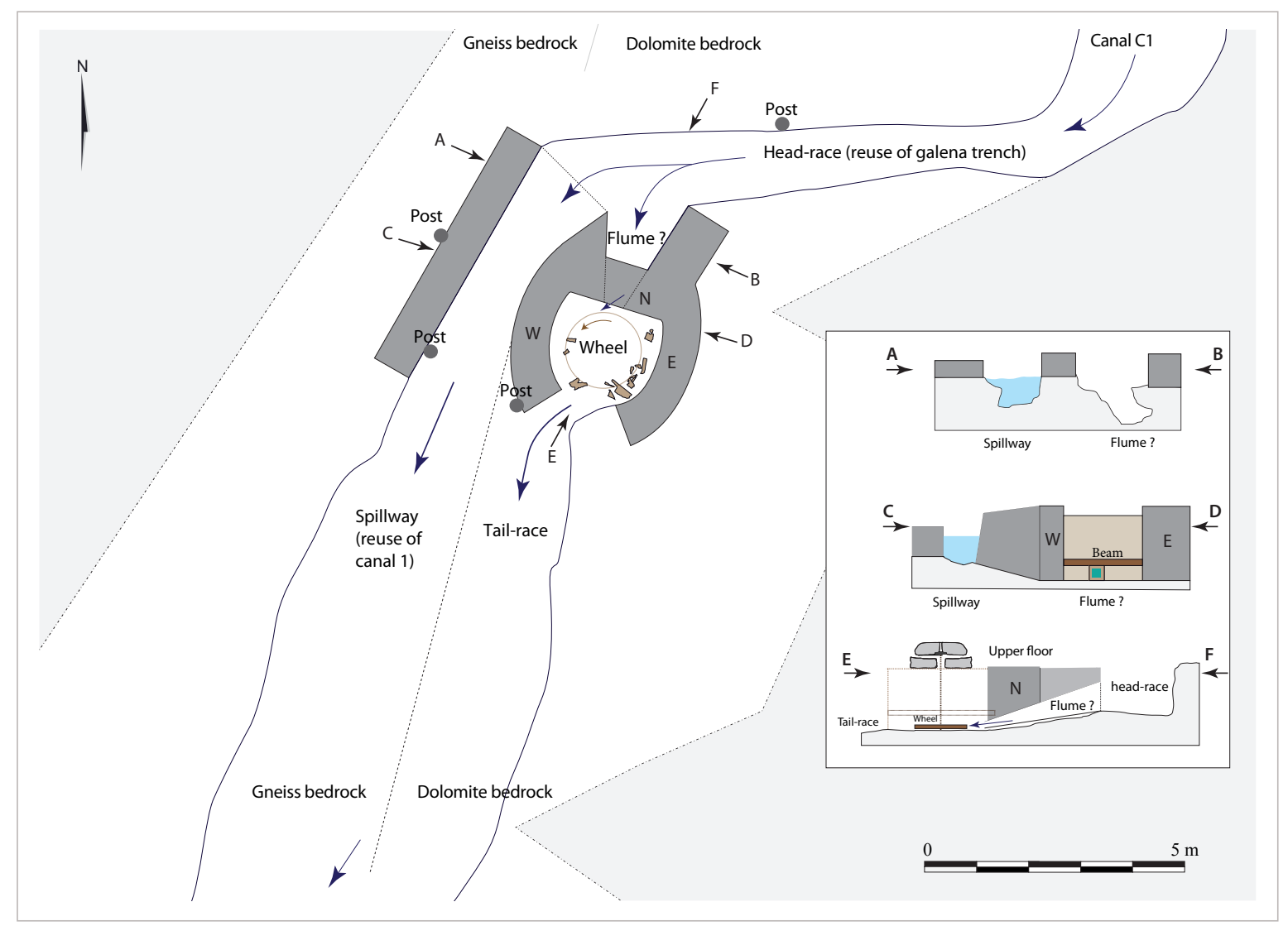

Fig. 5: Interpretative floorplan and cross-sections of the main features of the Brandes hydraulic ore mill. The limit between the gneiss and dolomite outcrops, essential to the understanding of the mill's organisation, corresponds to the diagonal line between the spillway and the tail-race (drawing by N. Minvielle Larousse).

\section{The head-race}

The head-race, the segment of Canal $\mathrm{C} 1$ to the north of the mill that steered water into the mill, traversed the dolomite bedrock along an east-west axis (Fig. 6). It is roughly $7.7 \mathrm{~m}$ in length and 80 $\mathrm{cm}$ wide. Taking account of the irregularities of the dolomite, this channel occupied a minimum area of $6.7 \mathrm{~m}^{2}$, and a depth between $1 \mathrm{~m}$ to the east and $60 \mathrm{~cm}$ to the west. Based on the average depth of $80 \mathrm{~cm}$, its volume can be estimated at 4.9 $\mathrm{m}^{3}$, a volume that it could power the mill wheel. From the stratigraphic standpoint, the head-race was first backfilled with layers of fine sands and homogeneous clays, followed by several timbers. This layer was then capped by a deposit of larger materials comprising rolled baryte pebbles.

The head-race of this mill has a distinctive origin (Amouric 1984, 78-89) as it originally served as an open-air trench with inclined edges cut into the bedrock (7.7 m long and 0.3-1.5 m wide) to exploit a vein of argentiferous galena. The ground plan of the galena trench originally corresponded to $6.4 \mathrm{~m}^{2}$ and its flat base varied from 1 to $1.5 \mathrm{~m}$ in depth.

Few clues have survived as to the techniques applied to extract the galena. There is no trace, for example, of the use of fire to weaken the mineral and there are only a few tool marks. A small working face preserved at its north-west end indicates two narrow, parallel trenches cut with a pick or chisel dividing the vein into three sections $10 \mathrm{~cm}$ wide. This cutting technique would have facilitated mineral extraction (Bailly-Maître 2002b, 80).

The vein was not fully exploited as $1-2 \mathrm{~cm}$ of galena remained along the north-east face. The western sector resulted in a face with a mineral still in place along a length of $1.1 \mathrm{~m}$. What remains unclear is if the miners exploited the mineral explicitly in view of digging the mill's head-race or if the mill makers took advantage of a galena trench after its abandonment.

Along the northern edge of the head-race, toward the middle of the trench, was a spruce post measuring $40 \mathrm{~cm}$ long and $12 \mathrm{~cm}$ in diameter, wedged with stones in a crack of the rock. Dendrochronological analyses of the post indicate is was felled about 1210/1211 (Archéolabs, ARC 13/R4021D/1). This post suggest the presence of other wooden structures along the head-race's northern edge. The trench's southern edge is less regular and showed no traces of a timber.

Due to the irregular shape of the head-race corresponding to that of the original trench exploiting the galena vein, its maintenance must have been tedious. Moreover, as there was constantly $60 \mathrm{~cm}$ of water at a minimum, there was probably a high rate of deposition of fine particles that would have gradually backfilled it. 


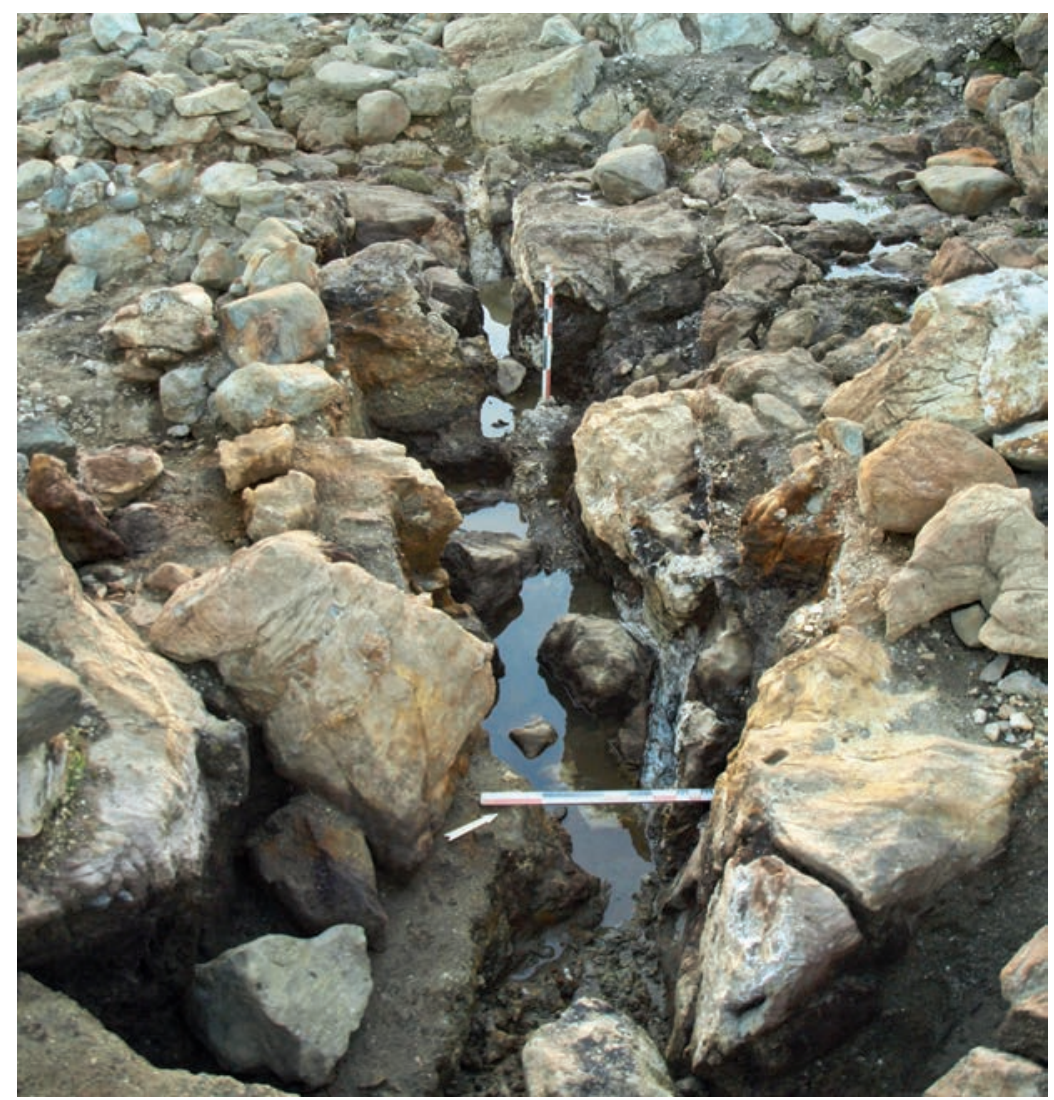

Fig. 6: View from the east of the galena exploitation trench that was re-used as the head-race to steer water into the mill from canal C1. The mill is in the background (photograph by N. Minvielle Larousse).

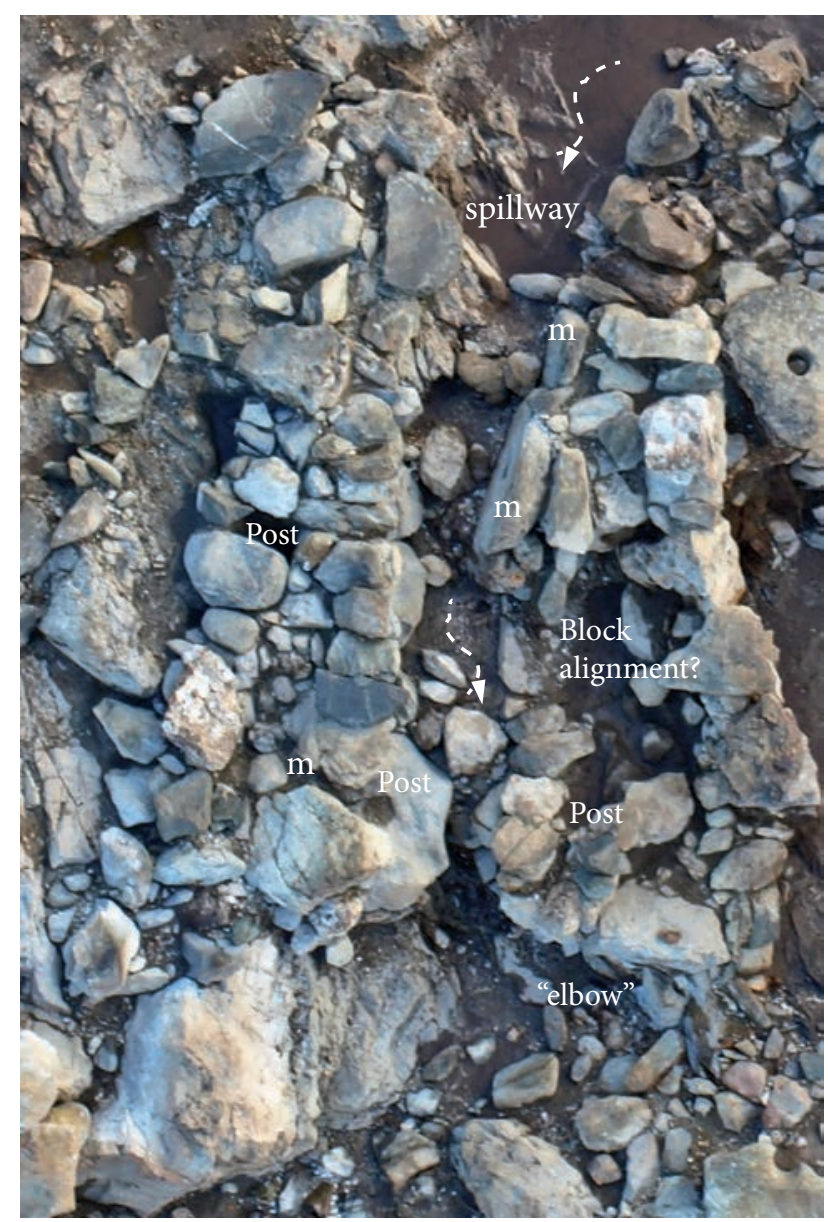

Fig. 7: Vertical view of the spillway. The millstones are indicated with an "m" (photograph by N. Minvielle Larousse). 


\section{The spillway}

The spillway of a mill is an essential feature that regulates the rate of flow when a mill is at work or permits bypassing the water wheel when the mill is at rest. At Brandes it is to the west of the mill and oriented NE-SW (Fig. 7). It is about $4.4 \mathrm{~m}$ long and $65 \mathrm{~cm}$ wide, resulting in a surface of $2.9 \mathrm{~m}^{2}$. Its base attains the gneiss bedrock that is $60 \mathrm{~cm}$ higher than the head-race. This is an essential detail as it permitted a large volume of water to be collected at the end of the head race adjacent to the mill's wheel chamber.

From north to south, the spillway's eastern edge was a drystone wall oriented NE/SW, $1.66 \mathrm{~m}$ long and $1.12 \mathrm{~m}$ wide, built with medium-sized blocks $(20-40 \mathrm{~cm})$ and recycled millstones. Two abandoned millstones dressed with furrows and bearing striations of wear were placed vertically along its inner edge indicating that the spillway was at least $70 \mathrm{~cm}$ deep. The spillway's eastern edge then continued downslope along a bedrock platform oriented NE/SW occupying an area of $2.21 \mathrm{~m}^{2}$ between the mill-house to the east and the spillway to the west. It is marked by an alignment $1.7 \mathrm{~m}$ long of a dozen medium-sized $(20-30 \mathrm{~cm})$ blocks. The third segment presents an elbow of $90^{\circ}$ to the east, with 3 blocks $1.3 \mathrm{~m}$ long in contact with the western wall of the mill-house. A wooden post, felled in 1227-1228 (Archéolabs, ARC 14/R4095D), and wedged with small blocks in the platform, is about $15 \mathrm{~cm}$ in diameter and preserved over a length of $36 \mathrm{~cm}$. This last group of features (under the water level at the time) is difficult to interpret. They probably correspond to elements of the base of the mill's timber superstructure.

The western edge of the spillway is formed by a drystone wall, $5 \mathrm{~m}$ long and $1.1 \mathrm{~m}$ wide oriented NE/SW. This wall contrasts with the other wall segments as it is massive and reinforced with timber. It occupies an area of $6.9 \mathrm{~m}^{2}$ with an inclination of about $30 \mathrm{~cm}$, and halts to the south just before a sort of step or tier nearly $80 \mathrm{~cm}$ high in the gneiss bedrock. At this point the spillway takes on the form of a classic construction with two parallel walls (only 1 to 3 rows are preserved). Several millstones are also included in this part of the construction. A whole runner stone is set to allow a spruce post 25 $\mathrm{cm}$ long and $10 \mathrm{~cm}$ in diameter to be inserted in its eye. Another post, a spruce $30 \mathrm{~cm}$ long and 12 $\mathrm{cm}$ in diameter, was wedged directly to the centre of the wall. It was presumably felled between 1210 and 1211 (Archéolabs, ARC 13/R4021D/1).

A sort of chute at the end of the spillway profited from a tier in the gneiss bedrock $90 \mathrm{~cm}$ higher on its eastern side that separated the canal into two distinct platforms. The course of the spillway, after the chute, continued $8.3 \mathrm{~m}$ downhill along a N-S axis, parallel yet separate from the tail-race. An alignment of three large discontinuous blocks totalling a length of about $1 \mathrm{~m}$ was arranged at the end of the spillway and served both to break the water flow and direct a part between it and the gneiss tier. Although crude, this feature was effective. Yet this contraption leads to the question of why the need to break the current? It may, in fact, have served to protect a washing feature downhill [ST 121-129]. As we have not observed any erosion of the washing structure's backfill, it seems that the blocks that broke the water flow served their function.

\section{The tail-race}

The tail-race is the canal serving to guide the water exiting the mill-house back into the original canal. The Brandes tail-race, only partially excavated, was deliberately dug by the miners for this purpose, as opposed to the head-race and spillway that profited from previously dug out features. Moreover, unlike the rest of the hydraulic system, the tail-race was deliberately backfilled in a second phase, after the abandonment of the mill. Its backfill consisted of a series of baryte waste deposits followed by a thick layer of rocks (Fig. 8).

The oldest backfills of the tail-race were identified in a trial trench. The deposit consisted of fine, sandyclay or stratified layers on an average $6 \mathrm{~cm}$ thick. These types of deposits are frequently observed in hydraulic features at Brandes. Although the trial trench was small and no characteristic artefacts were recovered, it is likely that the deposits were of hydromorphic origin resulting from operating the mill. Other anthropic backfills containing baryte debris were later deposited voluntarily throughout the length of the tail-race. Although the gravel and pebbles are mainly angular, some are rolled indicating they were transported by water.

How these deposits were formed and their function are sensitive issues. The first working hypotheses tended to see them a colluviums deriving from operation of the mill or other materials transported by water after the mill's abandonment. Yet this view was discarded as rolled elements were a minority and because the backfills, all homogeneous, are superimposed with well-defined limits. Therefore it is more likely that the deposits represent deliberate attempts to seal the tail-race. These backfills were ultimately capped by a thick layer of rocks, somewhat ordered, on the eastern border of the canal that served, on the one hand, to reinforce the canal to the west and contain a spoil heap to the east.

The precise course of the tail-race was not observed during the excavation as it was not possible, due to time constraints, to dismount all of the blocks in the area. It is assumed that the water from the mill exited the undercroft and ran to the south parallel to the spillway under the pile of rocks before joining the main canal. The water most likely followed a large fault in the dolomite bedrock $(1.5 \mathrm{~m}$ wide at its top and $25 \mathrm{~cm}$ at its bottom and $80 \mathrm{~cm}$ deep,) that outcrops uphill from the mill (Fig. 9).

This natural conduit, whose axis coincides exactly with the supposed position of the tail-race, was partly deepened and widened by the miners as seen in the trial trench (Fig. 10). Yet the excavation of these features did not bring to light artefacts that could substantiate the tail-race's contemporaneity with the mill, the sunken features and the backfill. 


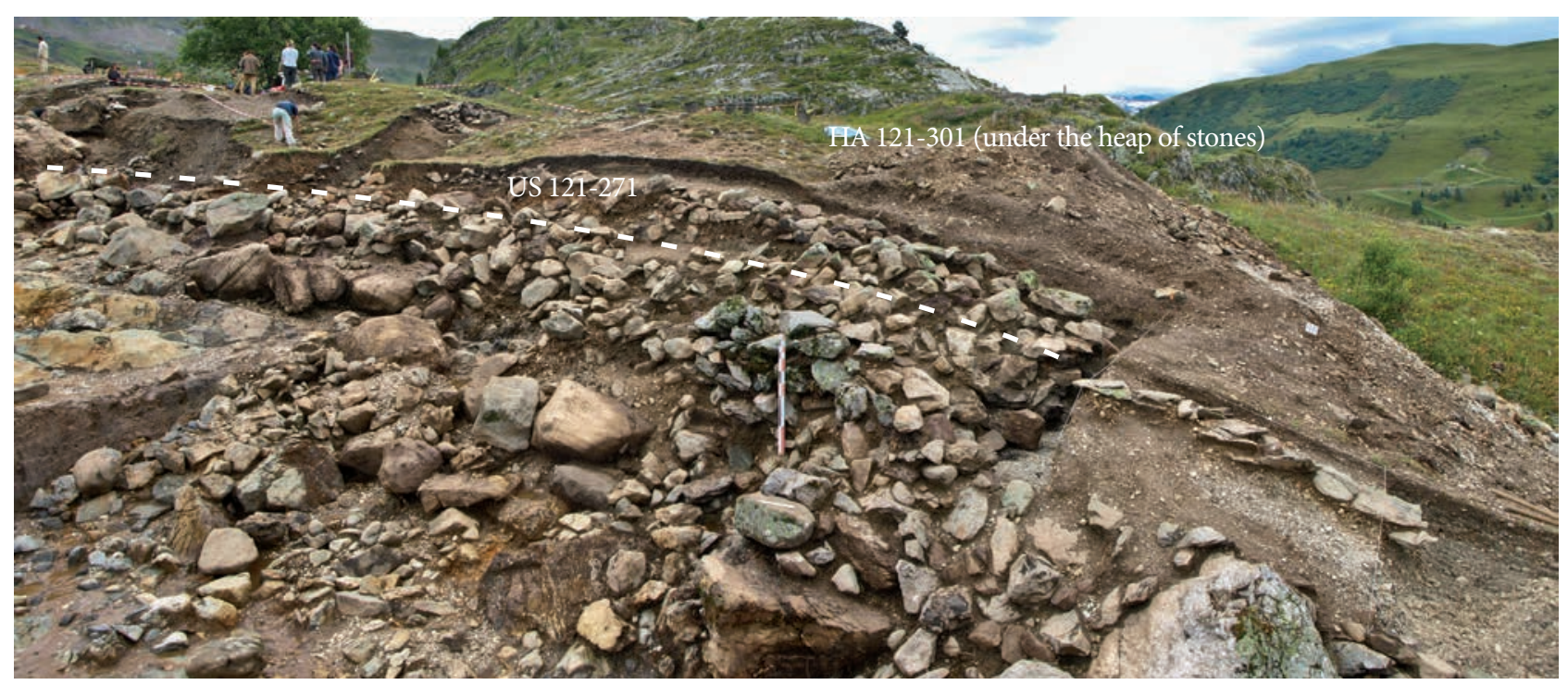

Fig. 8: View from the south-west of the area downhill from the mill. A linear fill of blocks marked by the broken line corresponds presumably to the course of the tail-race (photograph by N. Minvielle Larousse).

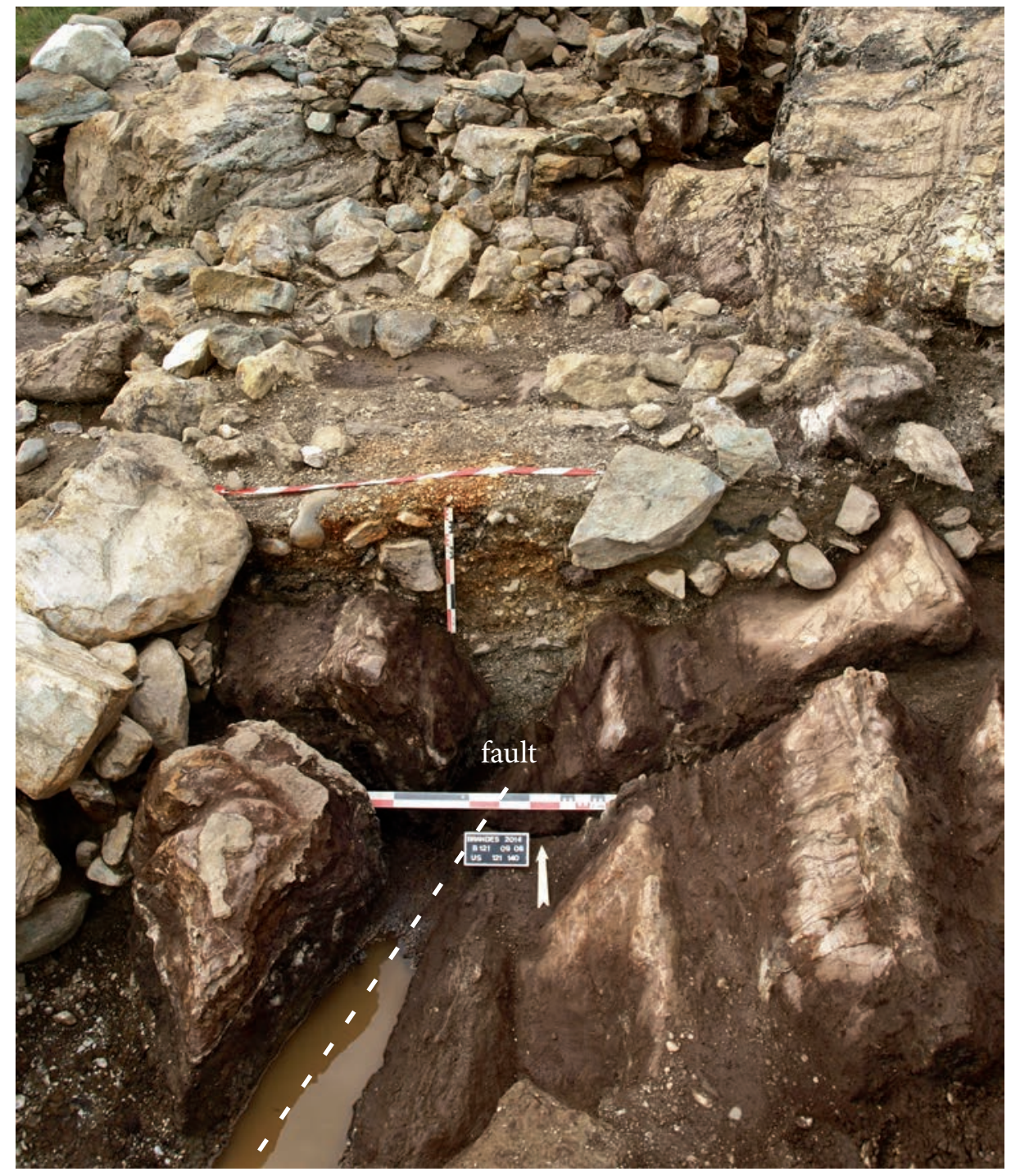

Fig. 9: Section indicating the fault in the dolomite bedrock at the junction of the spillway and the tail-race (photograph by N. Minvielle Larousse). 


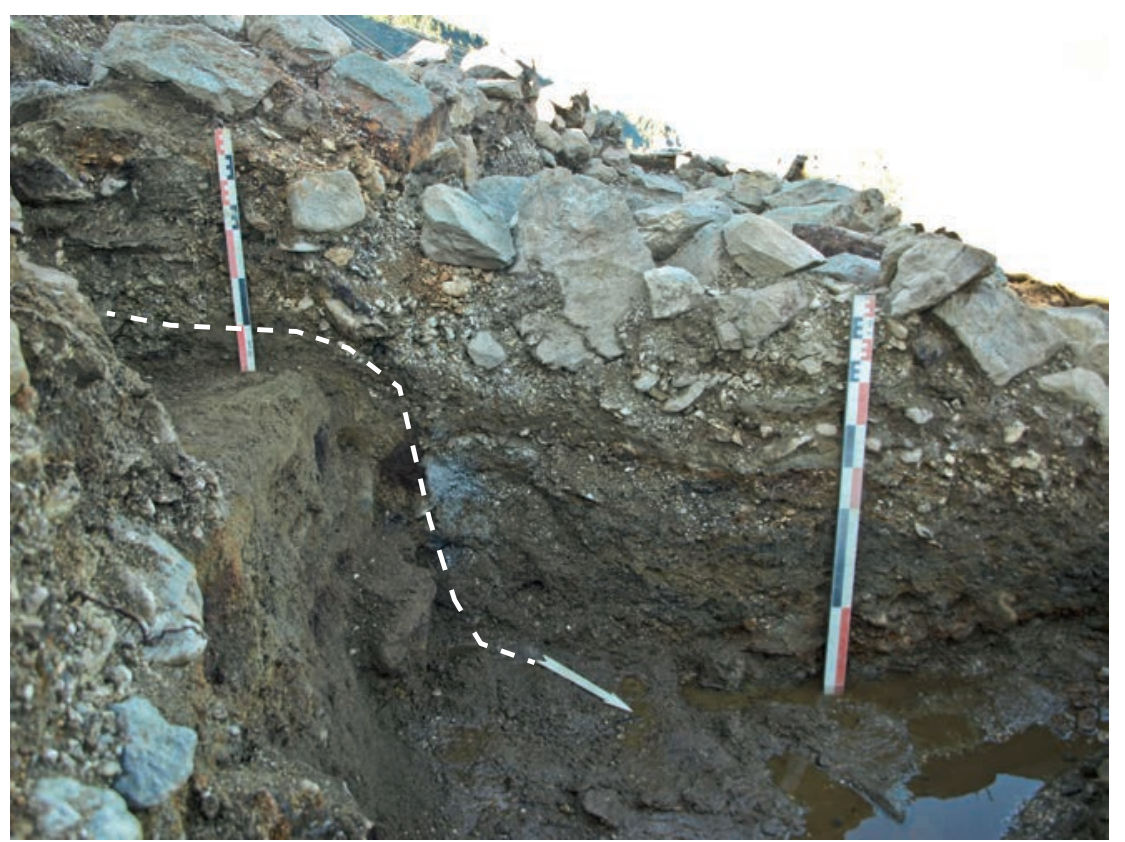

Fig.10: View of a section of the tail-race cut through natural deposits (photograph by N. Minvielle Larousse).

\section{The mill-house}

\section{The drystone walls}

The mill-house has a roughly horseshoe shaped foundation to the south of the head-race and east of the spillway. Its foundation comprises three drystone walls (east, west and north) with an opening to the south (Fig. 11). The house was presumably organised with two floors: an upper floor containing the millstones where the grinding took place and an undercroft containing the waterwheel. Each of the walls of the mill is singular from the point of view of size and construction. Despite the differences, all three were probably raised at the same time.

The space where the grinding took place on the upper floor, oriented N-S, measured presumably 2.1 $\mathrm{m}$ in length. Its shape was not regular as along its northern edge it measured $1.9 \mathrm{~m}$ in width, expanding to $2 \mathrm{~m}$ at its girth, and $1.4 \mathrm{~m}$ at the southern end. The total surface of the grinding floor ranged from a minimum of $3.4 \mathrm{~m}^{2}$ to a maximum of $5.2 \mathrm{~m}^{2}$.

The eastern wall measures $4.6 \mathrm{~m}$ long and $80 \mathrm{~cm}$ wide. It is the widest of the three. Besides small to medium-sized rocks $(10-30 \mathrm{~cm})$, it comprised, to the south, two large dolomite blocks about 1 $\mathrm{m}$ in length. Built directly on the bedrock in a narrow trench, its external face is irregular and merges with the surrounding blocks. The internal facing, by contrast, is much more organised and conserved to a height of $1.2 \mathrm{~m}$. Toward its northern end it curves slightly inwardly $(15 \mathrm{~cm})$.

The western wall, separating the chamber of the waterwheel from the spillway, measures $1.8 \mathrm{~m}$ in length and $80 \mathrm{~cm}$ in width with a base consisting of four large blocks. Its rough aspect contrasts with that of its eastern counterpart. It too presents a slight inward curve to the north that combined with the eastern wall results in the horseshoe shape.

Finally, the northern wall is $1.2 \mathrm{~m}$ long, $30 \mathrm{~cm}$ wide and preserved at a height of $1.4 \mathrm{~m}$. It delimited the house from the space reserved presumably for the flume.

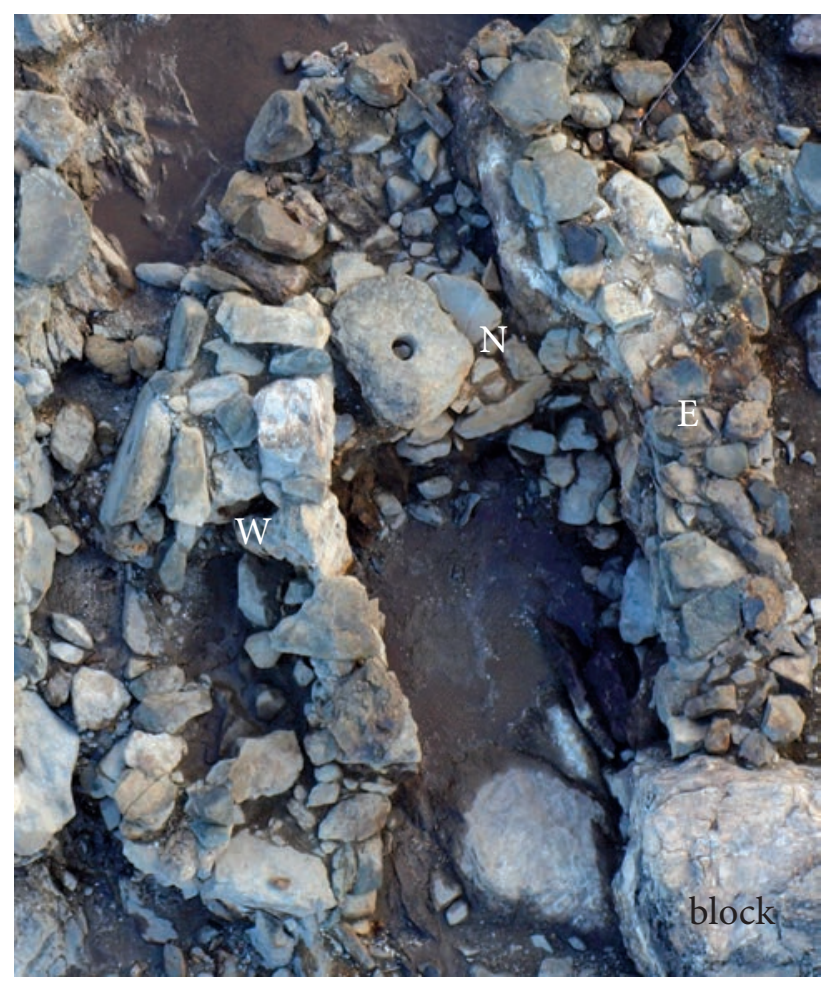

Fig. 11: View of the undercroft containing the water wheel and the three drystone walls making up the foundations of the upper floor of the mill-house (photograph by $\mathrm{N}$. Minvielle Larousse). 


\section{The backfill of the mill-house}

The backfill in the mill-house ranged from 1.2 and $1.4 \mathrm{~m}$ in depth. Its stratigraphy (from top to bottom) consists of four major deposits. The oldest is a layer of blocks and fragmented millstones in a heterogeneous, predominantly sandy, matrix. The size of the millstones in this level varies from small pieces a few centimetres long, to larger segments and halves (Fig. 12). This deposit capped a more homogeneous layer of gravel and baryte 5 to $20 \mathrm{~cm}$ thick containing many pieces of timber (see below) and a high concentration of millstone fragments (49). Finally, under the gravel and baryte, there were more fragments of wood and millstone flakes in a homogeneous grey to brown sandy layer. This layer did not contain blocks and only four millstone flakes, probably "infiltrations" from the upper units. This sandy layer rested on the top of the dolomite bedrock (Fig. 13).

The goal of analysing the mill-house stratigraphy was to determine, on the one hand, the nature of the deposits (deliberate demolition or natural colluviums), and if there are deposits associated with the mill's operation. The upper units containing the millstone fragments of different size in a sandy matrix are clearly post-abandonment formed either by the progressive demolition of the structures or by a faster intentional anthropic backfill. Both are associated with colluviums deposited by water running through the canal. The lower deposits, by contrast, appear to be contemporary to the mill given the high number of small millstone flakes and their uniformity while the oldest sandy layer could correspond to ore grinding residue.

\section{The undercroft}

The base of the undercroft of the mill-house coincides with the summit of the dolomite bedrock. It presents an inclination of about $30 \mathrm{~cm}$ from its $\mathrm{N}-\mathrm{W}$ corner to its S-E corner. In fact, a sort of channel is formed along its summit along the base of the eastern wall leading to the S-W. This feature, $2 \mathrm{~m}$ long and about $10 \mathrm{~cm}$ wide, then carries on for about $1 \mathrm{~m}$ along the base of the western wall before changing course and joining several faults in the dolomite oriented NW-SE (Fig. 14).

This asymmetry would have facilitated the evacuation of water by a channel drawn diagonally to the house through the faults in the dolomite serving as the tail-race.

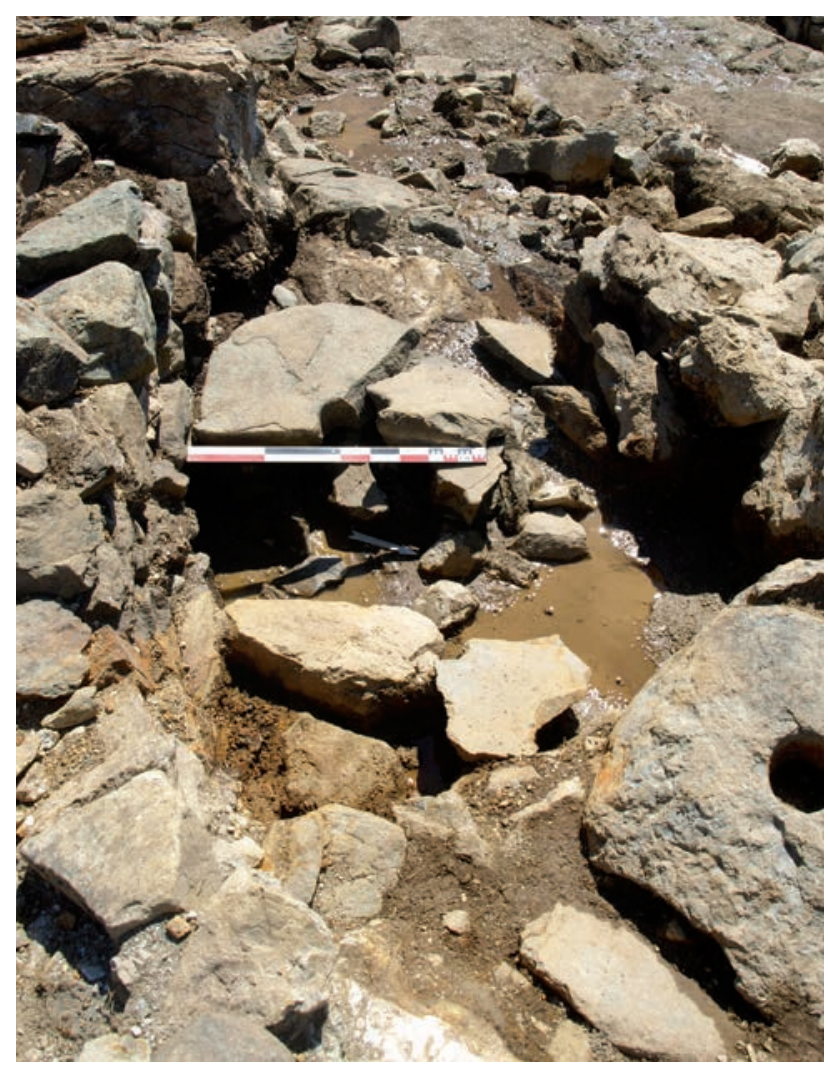

Fig. 12: Upper layers of the backfill of the undercroft containing blocks and large millstone fragments (photograph by N. Minvielle Larousse).

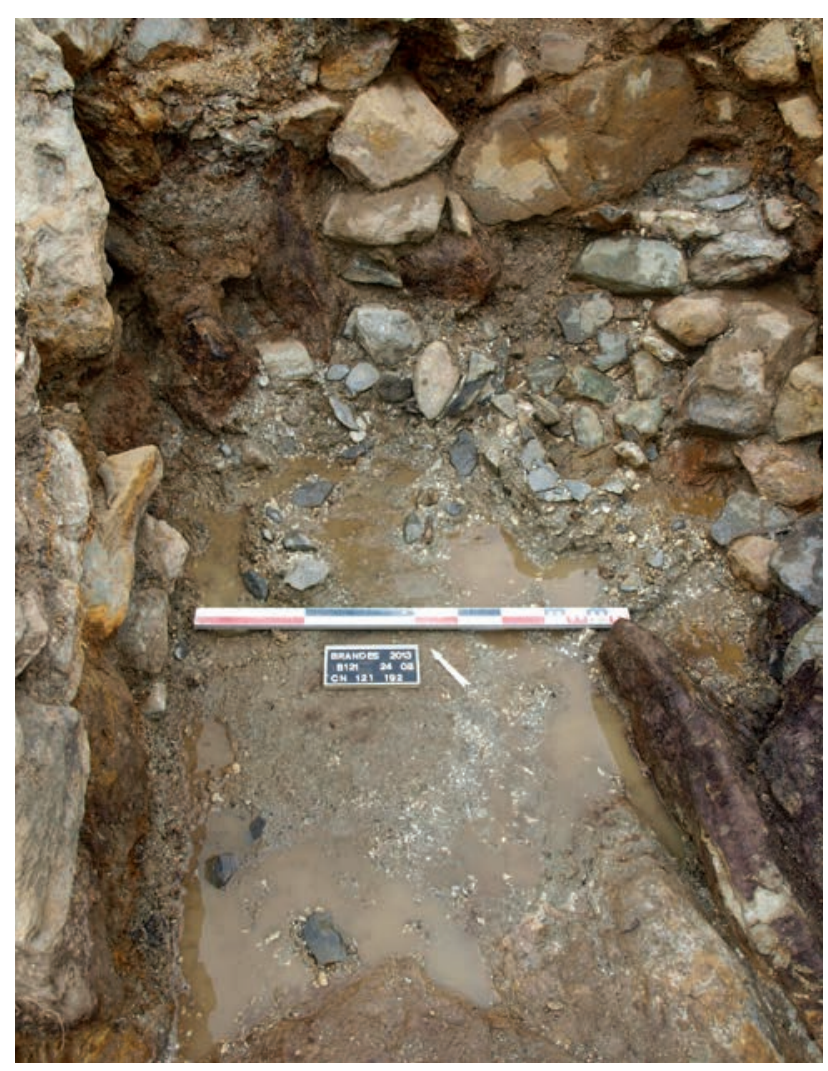

69

Fig. 13: Lower layers of the backfill of the undercroft containing wood fragments, a great number of millstone flakes and ore grinding residue resting on the dolomite bedrock (photograph by N. Minvielle Larousse). 


\section{A wooden flume?}

The flume in a watermill equipped with a horizontal waterwheel is an inclined, tapered wooden feature that traverses the wall of the mill-house allowing the flow to be directed from the head-race into the waterwheel chamber and drive the wheel by means of a jet of water. In the case of Brandes, the cavity holding a hypothetical wooden flume measured about $2.1 \mathrm{~m}$ in length (N-S) and $1.4 \mathrm{~m}$ to $60 \mathrm{~cm}$ in width.

The flume would have been wedged diagonally in the space between a block bordering the head-race to the north and the northern wall of the undercroft (Fig. 15). This type of feature is evidenced by a horizontal wooden beam (Figs 16 and 17) fixed toward the base of the north wall serving as a sort of lintel above a quadrangular hole backfilled with baryte sand connecting the cavity to the waterwheel chamber. This hole would have been traversed by the nozzle of the flume.

The wooden beam has a central mortise suggesting the presence of a second beam projecting from it perpendicularly. The hole under the beam connecting the two cavities measures about $30 \mathrm{~cm}$ in height

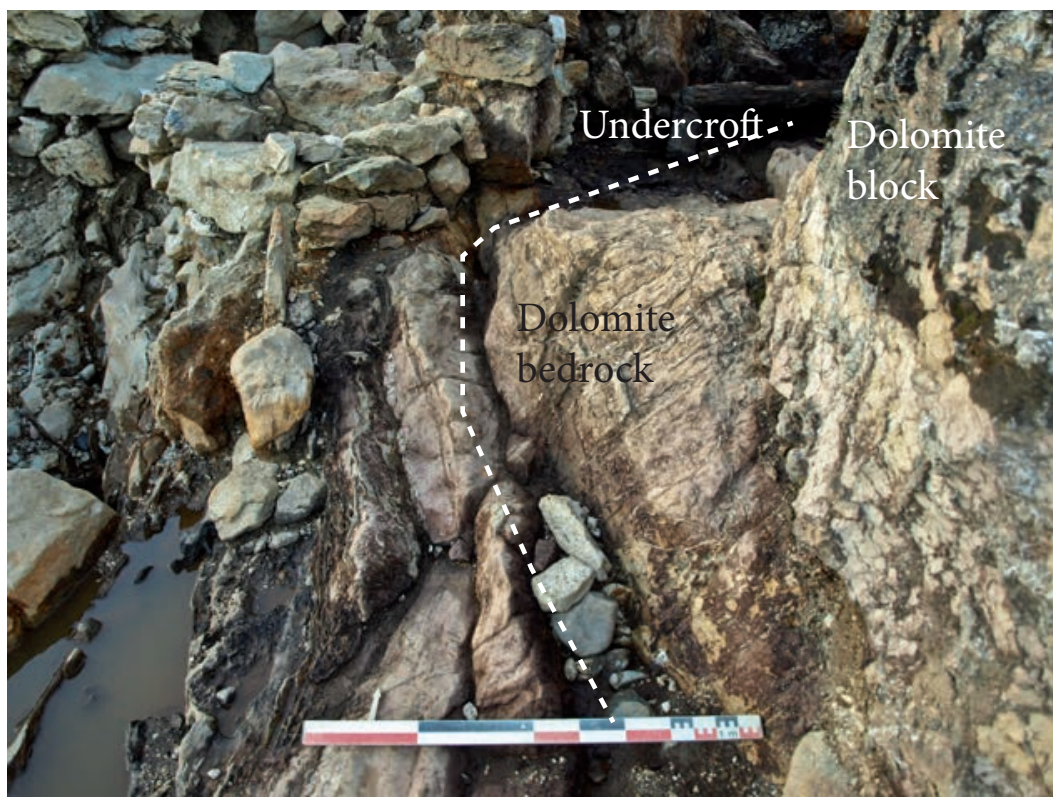

Fig. 14: The dissymetrical form of the undercroft and the exit to the tail-race as seen from the south (photograph by N. Minvielle Larousse).

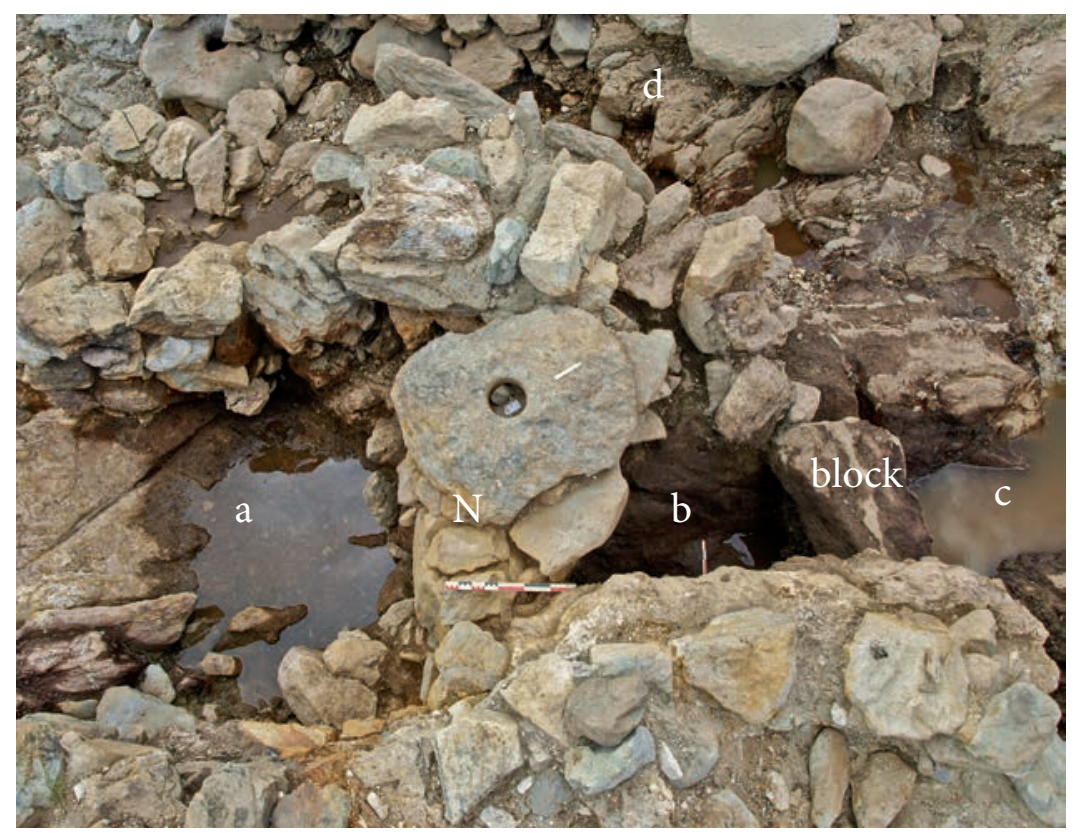

Fig. 15: View of the main features of the mill's hydraulic system: a) undercroft, b) flume and c) head-race. The north wall separates the undercroft from the flume. The flume is separated from the head-race by the block (ST 121-184). The spillway (d) to the west skirts the mill (photograph by N. Minvielle Larousse). 


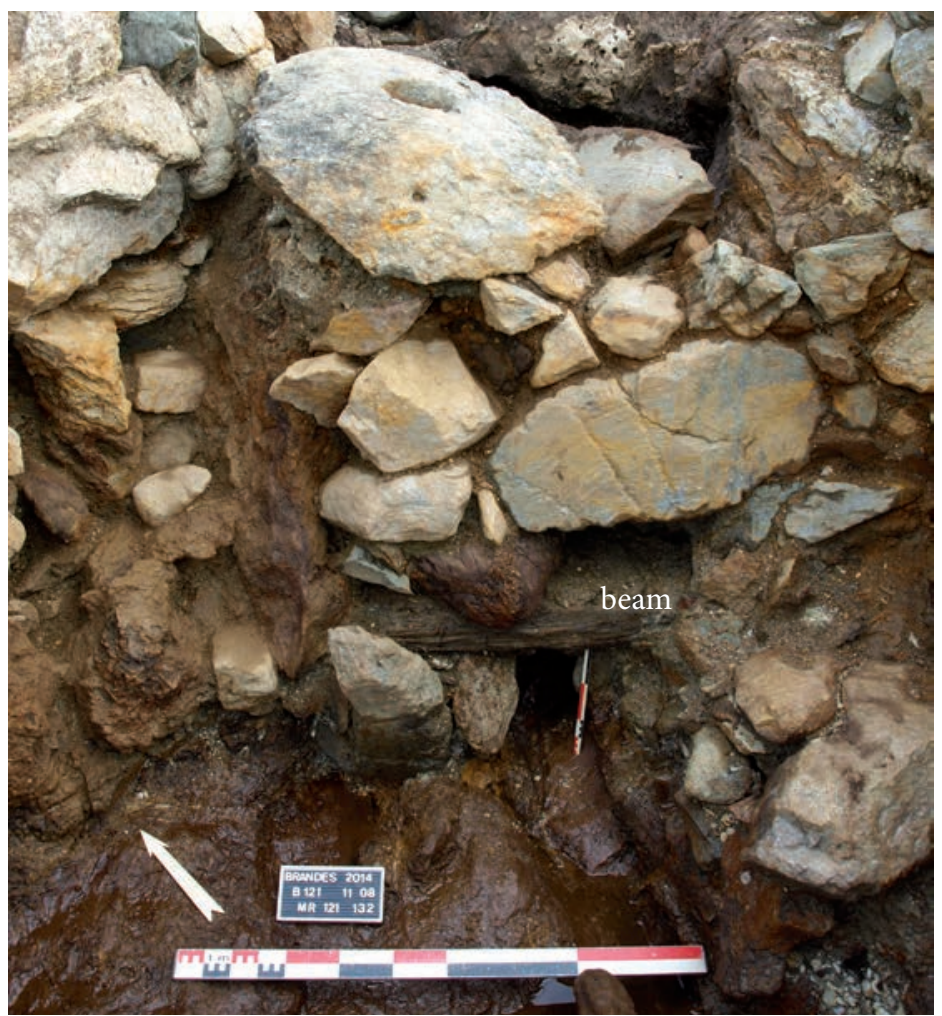

Fig. 16: The horizontal wooden beam is toward the base of the undercroft (photograph by N. Minvielle Larousse).

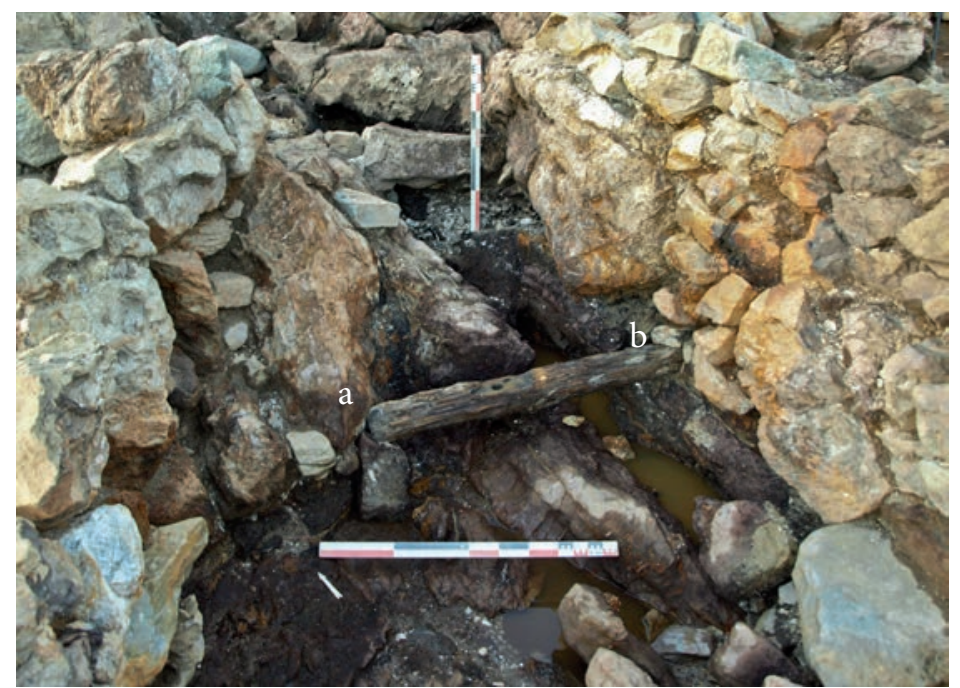

Fig. 17: View of the wooden beam with the central socket separating the flume from the undercroft (photograph by N. Minvielle Larousse).

and $20 \mathrm{~cm}$ in width and was backfilled with sand and rolled white baryte gravel.

The hypothesis of a wooden flume is bolstered by the sediments observed during the excavation of the cavity between the undercroft and the head-race. From top to bottom they consist of an accumulation of blocks in a baryte sandy matrix similar to that at the base of the undercroft. This layer appears to correspond to deposits accumulated during operation of the mill. This notion is bolstered by the fact that it contained 73 millstone flakes.
The next layer consists of sand and blocks covering units of sand and rolled baryte gravel similar to the facies backfilling of the head-race. The final unit is the dolomite bedrock that shows an irregular shaped cutting about $1 \mathrm{~m}$ below the base of the walls measuring between $1 \mathrm{~m}$ to $30 \mathrm{~cm}$ wide and $2 \mathrm{~m}$ long. The cutting clearly connects the western end of the head-race to the base of the mill-house that is on an average about $55 \mathrm{~cm}$ downhill. This cutting profited from one of the dolomite faults, perpendicular to the exploitation of the vein, and appears to have been slightly extended. 


\section{Operation and evolution}

\section{Horizontal or vertical waterwheel?}

Although the poor state of preservation of the Brandes mill does not allow determining beyond any doubt the means of traction, there are a number of features that suggest a horizontal waterwheel.

The first is the mill's floor plan. The undercroft's horseshoe shape and dimensions are compatible in width with a horizontal waterwheel. Furthermore, the inclination of the base of the undercroft could have served to guide the water from north to south through a fault in the dolomite bedrock to the west. This dissymmetry would not have been necessary in the case of a vertical water wheel.

The general hydraulic system is also compatible with a horizontal water wheel. The northern wall was designed to take advantage of a fault in the dolomite that steered the water to the nozzle at the end of the flume to power a horizontal wheel. A flume can therefore also be inferred from the higher base of the adjacent spillway (in comparison to the base of the head-race) that allowed the retention of a great volume of water that could be directed either through the flume to the waterwheel or bypassed through the spillway during heavy rains or when the mill was at rest.

The hypothesis of a vertical wheel at Brandes is, in turn, hampered by two key elements. A vertical wheel, connected to the millstones by means of a complex gearing system designed to convert a vertical to a horizontal motion would have had to be located not in the undercroft but in the spillway. But since the base of the spillway at Brandes is higher than that of the head-race, the level of a horizontal driveshaft and gearing system connected to a vertical wheel would have been far too high in relation to the theoretical height of the floor of the mill-house.
What is more, reversing the location of the vertical wheel chamber and the spillway would have required the overflow of water, when the mill was not active, to flow through the "flume". But this second conduit, with only a small cavity at its base, would have been too narrow to cope with the large flow from both the spring and Canal C1.

Furthermore, a vertical waterwheel in the spillway would have had to be placed at the outset of the spillway, a location that would not apparently have been apt for a wheel driven by undershot.

\section{A flume}

A flume, in general, is a hollow wooden feature with an inverted, truncated pyramid shape, like an elongated mill hopper. A fine example was recently discovered during excavation of a mill of Kilbegly in Ireland (Jackman 2013, 5). The base of the flume can be prolonged by a nozzle. Although the size and shape of flumes can vary, their function remained the same: to direct a jet of water under pressure against the wheel.

In the case of Brandes, the theoretical wooden framework of the flume was set in a cutting carved into the dolomite bedrock. Yet, the direction of the cutting through the bedrock ending toward the south-eastern corner of the flume's cavity does not match the inclination of the undercroft. In fact, the stream of water would normally have been directed from the east yielding a clockwise horizontal wheel rotation. But the asymmetry of the bedrock is such that the water circulated diagonally from the northeast to the south-west resulting in a counterclockwise rotation of the wheel. This operation would therefore have required a short, angled spout at the end of the flume to direct the stream of water first along a north-south axis through the hole under the beam before veering to the south-west to make contact with the paddles of the waterwheel.

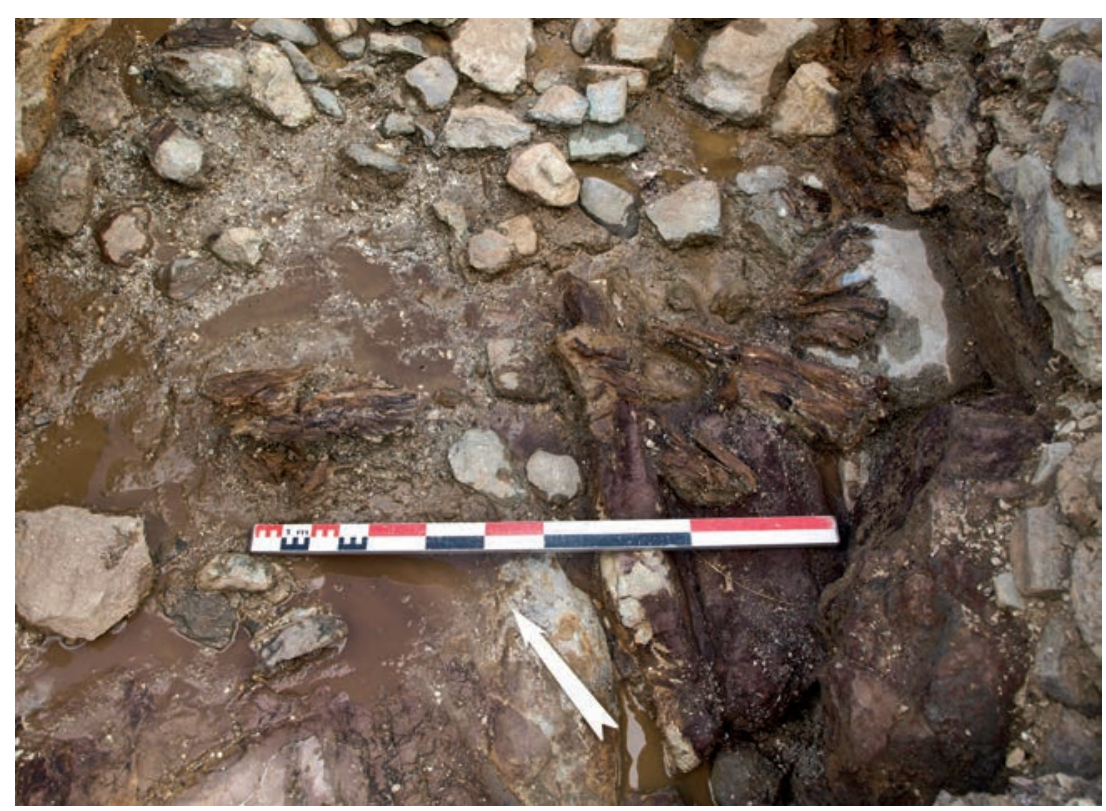

Fig. 18: Wood fragments along the base of the undercroft that could be remains of the waterwheel (photograph by N. Minvielle Larousse). 


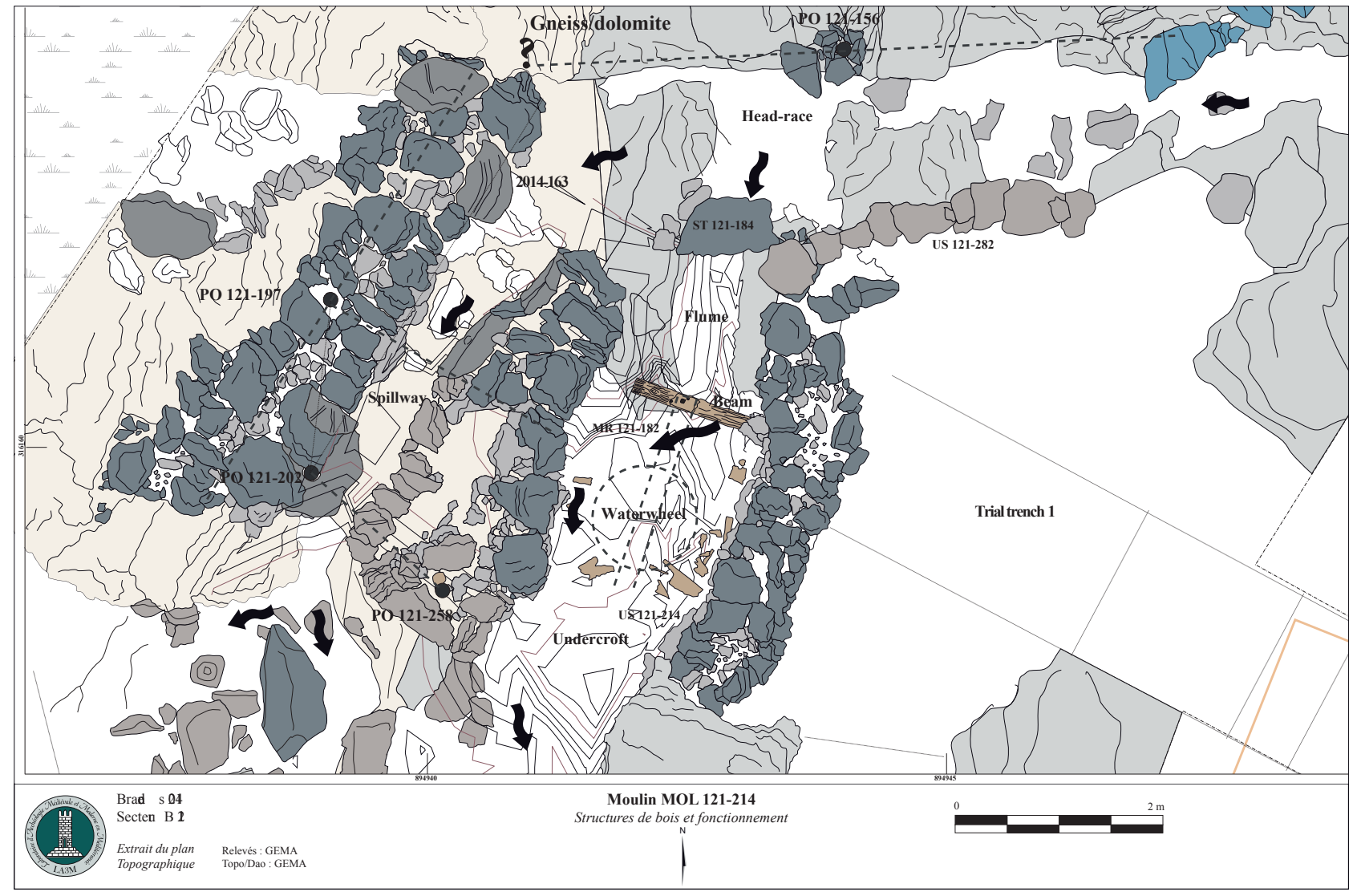

Fig. 19: Map with the position of the different wooden features (beam, posts) and hypothetical position of the wooden superstructure, horizontal waterwheel and direction of the flow of water through the wheel chamber suggesting a counterclockwise waterwheel rotation (drawing by N. Minvielle Larousse).

\section{Remains of the waterwheel?}

At the base of the undercroft, the successive stripping of the heterogeneous sandy deposits brought to light several pieces of wood resting at the summit of the bedrock, toward the base of the eastern wall, on the blocks and on a layer of baryte gravel mixed with pebbles (Fig. 18). Unfortunately the different pieces of wood are poorly preserved and their specific form and eventual tool marks are not discernible. Yet their spread is arranged in a tangential and radial scheme forming a sort of "circle" approximately $1.5 \mathrm{~m}$ in diameter. It therefore cannot be excluded that these pieces of wood are the remains of a horizontal waterwheel equipped with spoon-shaped blades around its central hub. A second option is that the pieces of wood correspond to the superstructure that supported the millstones.

\section{The wooden superstructure}

Based on the reconstruction of the initial position of the beam toward the base of the north wall, and taking into account the notch or slot cut into the wall, we can assume the presence of a similar second perpendicular beam projecting southwards from the central mortise (Fig. 19). Unfortunately its length is unknown as there is no visible mark cut into the dolomite bedrock on the opposite side of the undercroft.

It is difficult to establish a relation between this second hypothetical perpendicular beam and the horizontal wheel. The beam's level, in any case, higher than the base of the undercroft or the spout of the flume, excludes that it served as a support for the horizontal wheel. By contrast, its position suggests it could have served to stabilise the mill's vertical driveshaft that powered the millstones. Another option is that it did not stretch over the length of the undercroft, excluding a relation with the waterwheel, but in some way forming part of the mechanism supporting the millstones.

The mill-house's superstructure comprised at least three wooden posts. The first, PO 121-258, is toward its south-west corner while the two others (PO 121197 and 202) are on either side of the spillway's western wall. Post 121-197 was probably integrated into an alignment that was parallel, perpendicular (or both) to the western wall. In the first case, two other posts along the wall's edge are missing. In the second case, the alignment could correspond to a gap at the southern end of the spillway's eastern edge. But here, too, an additional theoretical post, or at least a notch on the wall, is missing. Post 121-202 could also be part of an alignment parallel 
to the wall. But here, once again, the theoretical posts to the north and south are missing. It could also be part into a perpendicular alignment and would, in this case, be linked to post 121-258.

In any case, the few posts that have survived, including post 121-156 to the north-east of the head-race, do not offer enough data to securely reconstruct the mill-house's timber superstructure.

\section{The flow of water}

While the surface of the dolomite bedrock suffered from decalcification and karstification due to prolonged contact with moisture, the harder gneiss bedrock remained largely unaffected except for a rounding and smoothing of its edges visible in the spillway where it was subject to a regular flow.

The flow of water also had an effect on a millstone (OBJ 2014-163) placed vertically in the eastern wall of the spillway with its grinding surface facing the water (Fig. 19). The upper limit of the wear on the stone, $30-40 \mathrm{~cm}$ above its base, indicates the normal level of the water running through the spillway. Similarly, the rocks of the lower rows of wall MR 121-171 are greatly weathered as opposed to the upper layers of the same wall where the blocks retained their original angularity. These features indicate a regular and strong current of water.

\section{The millstones}

A large number of elements of millstones (125 fragments and 309 flakes) were found in the mill and its immediate surroundings. Their average diameter is estimated at $110 \mathrm{~cm}$. Among the 125 fragments, there are four that are practically whole, five halves, 13 segments and many other fragments of different sizes. The largest concentration of fragments and flakes was in the mill-house (44 fragments and 220 flakes). Some fragments were scattered in either the backfills of the spillway and the tail-race while others (19) were re-cycled as building material in the mill's structures. This material is currently under study for a future publication (Minvielle Larousse, in press).

\section{The evolution of the mill}

The reuse of millstone fragments as construction material, some at the base of certain structures, indicates that the excavated mill was preceded by at least one other mill raised either in the same spot or nearby. The construction of the excavated mill, based on dendrochronological analyses of at least two of the posts, can be precisely dated to 1210-1211 AD. Moreover, post 121-197 was still green indicating it was raised shortly after it was felled. The date of the felling of the beam serving to support part of the wall of the flume, in turn, came sometime after 1201, a range that is not inconsistent with a construction in 1210 .

Furthermore, the wooden superstructure of the mill was revamped or extended with timber felled in 1227/1228 AD. Finally, a piece of wood recovered in the backfill of the head-race, hence most likely dating to the mill's abandonment, was felled after 1223, possibly in 1228. Yet this second date must be considered with caution as the wood is in secondary position and many years could have elapsed before it found its way into the head-race.

It is therefore certain that the ore mill of Brandes was in operation in the first half of the 13th century. This is bolstered by the 13th century date attributed to the metal working area upstream of sector B 102 linked to the mill by means of canal $\mathrm{C} 1$.

In spite of a clear date for the mill's construction, there is, in turn, little evidence of its abandonment. The dendrochronological analysis corresponding to repairs in 1227/1228 suggests that the mill operated for at least 17 years. Yet the date of the repairs does not constitute an terminus ante quem and the mill could have seen use beyond that time frame.

\section{An industrial mill}

The layout of the mill was designed to concentrate all of its features in the smallest possible space (Fig. 20). Taking into account the head-race, the tail-race, the spillway and the mill-house, the mill occupied a surface of $62 \mathrm{~m} 2$. Its total length from the northern end of the head-race to the southern end of the tail-race was about $20 \mathrm{~m}$. The width of the mill-house was $5.5 \mathrm{~m}$ and the length of the mill-house, including the flume, was $4.6 \mathrm{~m}$.

\section{Construction and architecture}

The mill's construction was clearly defined by the outcropping of the bedrock as it profited from the natural features inherent to the junction of the masses of dolomite and gneiss. The mill-house, for example, was set on the dolomite so as to take advantage of the faults running east-west for the head-race and the north-south faults for the flume cavity. The tail-race also profited of a north-south fault in the dolomite to evacuate the water. The spillway, in turn, was built on the gneiss and benefited from a raised section of the rock to separate it from the tail-race.

In addition to the opportunism in the choice of the location, the builders of the mill applied a very rudimentary construction technique using rough, unworked blocks of different size. This indicates that there was no regular supply of building materials from a specific quarry or of a specific type of rock. To gain in time and expense, the mill was in fact built with readily available local surface materials. This also explains the reuse of many millstone fragments as construction material. In addition, many of the dolomite blocks may have come from the spoil resulting from the cutting the trench of the head-race, the levelling the bedrock under the future mill-house or the digging out the mill's wheel-chamber. 


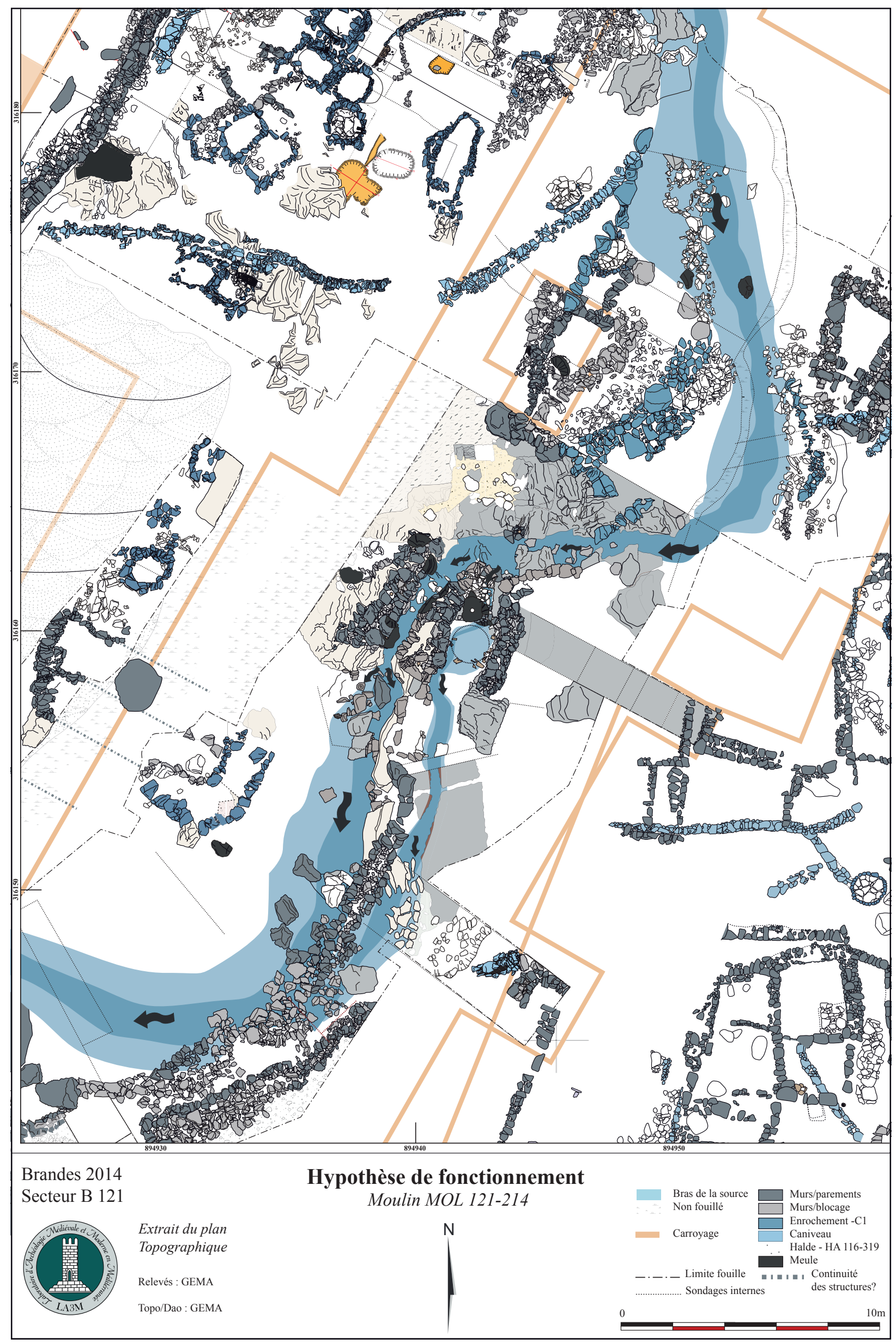

Fig. 20: Hypothetic reconstructoin of the mill's hydraulic system. The arrows indicate the currents of the different features (drawing by N. Minvielle Larousse). 


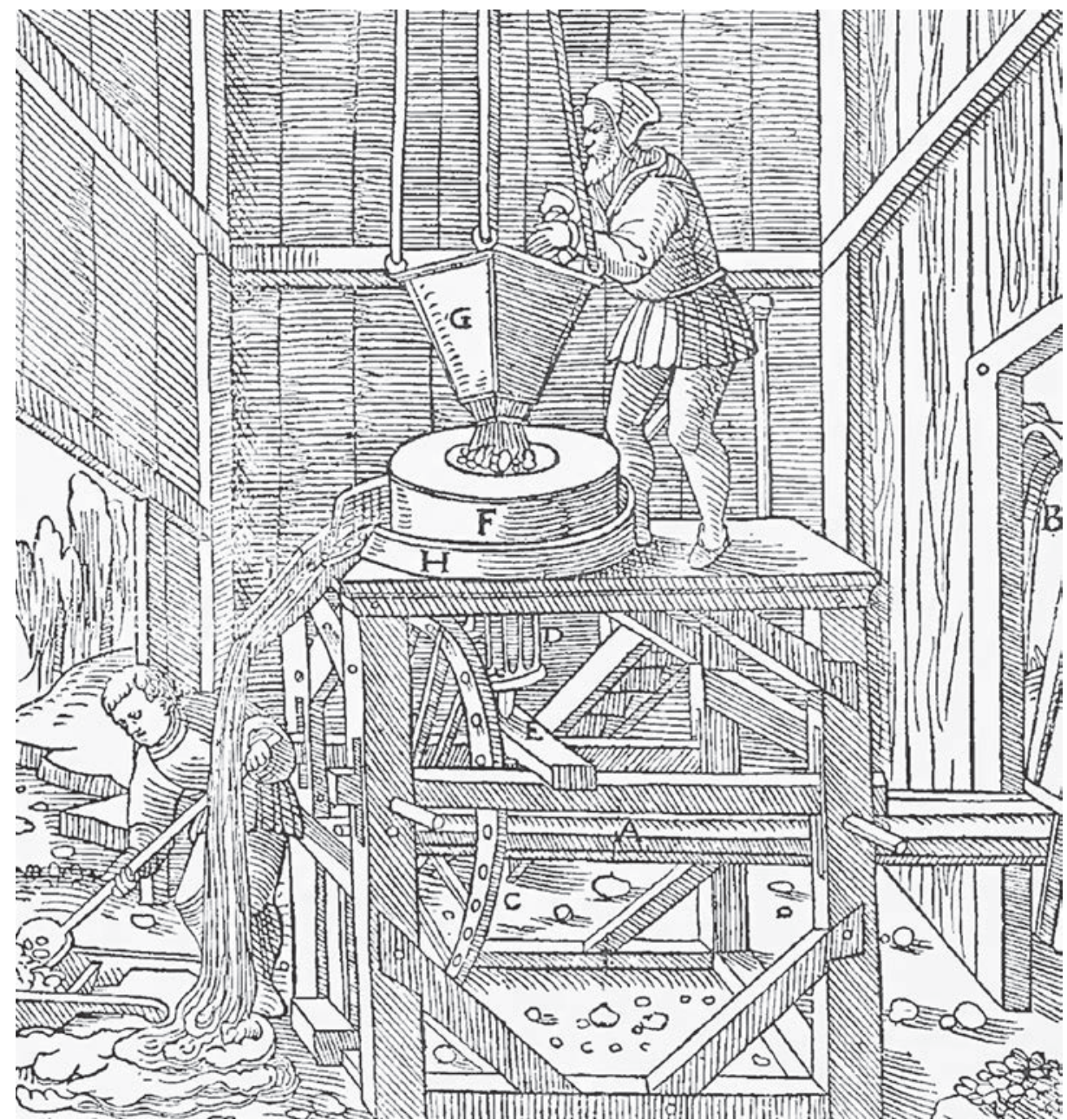

Fig. 21: Agricola's 16th-century ore grinding mill (from Agricola 1950, 294).

While the mill of Brandes used stones for its foundations, wood served for the wheel and gearing mechanisms and to support the superstructure. There is no indication of the use of iron in the construction. This absence appears to be deliberate as smithies are common to Brandes. The hypothetical elevation of the Brandes mill therefore differs from the ore mill represented in the 16th century engraving by Georgius Agricola (Fig. 21) (Agricola 1950,294 ) housed under what is a structure raised entirely of wood.

The Brandes mills therefore may have been simply an open platform as grinding ore, contrary to grinding cereals, for example, would not have required protection from the elements.

\section{The mill mechanisms}

In general, the horizontal waterwheel places the Brandes mill in a broad technical context. Horizontal wheels, one of the simplest driving mechanisms, have been regarded in mill literature as primitive (Bloch 1935) or as the ancestor of the vertical wheel (Braudel 1993, 400). Contrary to this pejorative view, it has in fact been demonstrated that the horizontal wheel existed since the origins of hydraulic milling, was contemporary to the vertical wheel (Comet $1992,439)$ and was bound to specific geographical areas (Benoît 2014).

Recent field work suggests that vertical wheels during the Early Middle Ages coincide with regions that were under Roman control, whereas horizontal wheels were restrained to the "barbarian" regions, outside Romanised spheres (Benoît 2014). However there are exceptions to this rule.

In Central Europe in the Middle Ages, the horizontal wheel was in fact widespread both in Provence and the Dauphiné despite a limited number of historiographic records (Amouric 1984, 130). The larger number of written accounts regarding verticals wheels in the Dauphiné is probably due to their exceptionality when compared to their horizontal counterparts. For example, the Huez flour mills (Combe Basse), mentioned in records as early as the 14th century (Minvielle Larousse 2009, 130-132), are known to have been driven with horizontal wheels as late as the 19th century. The mill of Brandes, therefore, follows in the wake of this tradition. 


\section{A functional mechanism}

Since the blocks used to build the mill were not fashioned, not even roughly squared off, we can assume the mill was constructed hastily without concern for its appearance. The early 13th century is a particularly active phase of mining at Brandes. It is therefore logical that additional installations were added to treat the ore when the quantity mined exceeded its processing capacity. An analogous situation is recorded at the Mine of Orzals (France, Aveyron) in the second half of the 13th century when the Count of Poitiers, desiring to immediately increase ore processing, sent a number of letters to his officers demanding that they rapidly construct all types of mills (water, animal, wind) to increase production (Dossat 1975, 91). Moreover, the materials used to construction the Brandes mill suggests that there was no intent in raising an ostentatious mill, as was the case at times of contemporary grain mills. The aim of this ore mill was strictly functional, tied to the necessity of boosting production.

\section{The ore mill in the mining operational sequence}

This mill was not the only 13th-century mill at Brandes. Besides traces of an earlier mill in the immediate whereabouts, there was at least one other mill further upstream on the C1 Canal (Minvielle Larousse et al. 2011a, 474-77). Yet the number of mills was very low compared to the quantity of crushing workshops and washing basins. In fact, water mills were not essential or used systematically in the operational sequence. In any case, two concentrations of sand deposits associated with millstone flakes were found in washing basins to the west indicating that they served to process materials ground in the mills. Yet the coexistence of sand with millstone fragments was identified in only two of the many washing basins. This bolsters the notion that mills at Brandes played a minor role in the ore enrichment process.

Regarding the organisation of the working process, grinding, contrary to crushing (and possibly washing), required collective equipment implying a specific type of management and taxation. No written text has survived that throws light on this question at Brandes. Nevertheless, ore grinding in other regions, like grain milling, was integrated into the seigneurial economy (Belmon 2003, 271-273).

This leads to the question of whether the leaders of society prompted the passage from manual to hydraulic grinding. For the period of Antiquity, in fact, no hydraulic ore mill is currently known (Pulou et al. 1997) in spite of a wide dissemination of watermill technology (Brun and Borréani 1998, 307-318). Therefore, did medieval miners have needs beyond that of their earlier Roman counterparts that required the systematic use hydraulic power for ore grinding? Yet since the constraints due to the type of ore and the will to optimise production were probably identical in Medieval and Roman times, the need of hydraulic power to drive the ore mills was therefore probably an imported idea.

\section{Conclusion}

Ore grinding at Brandes up to recently was the only stage of the ore enrichment process that remained in the shadows. The results of this excavation campaign, in conjunction with the study of the millstones, offers a broader view of the ore enrichment process, from the phase of extraction to that of working the metal. Moreover, this mill is an addition to the ever growing list of excavated medieval hydraulic works and another example of the use of water power in medieval industry. Data gleaned from archaeological work at times raise more questions than they answer, and the problems of interpreting certain features are much more complex than initially considered. Thus, the excavation of the Brandes ore mill is another element in the growing discussion of the process of innovation and mechanisation of mining in Antiquity and the Middle Ages.

\section{Acknowledgments}

It is a pleasure to thank all those who have assisted this research: Timothy Anderson, Henry Amouric, Marie-Christine Bailly-Maître, Natacha Barre, Beatrice Cauuet, Petr Hruby, Luc Jaccottey, Flavien Perazza, Florian Téreygéol, Martin Watts and, of course, the diggers of the Groupe d'Etude des Mines Anciennes who worked very hard moving the blocks that covered the archaeological vestiges. A special thanks goes to Jean-Pierre Brun and Luc Jaccottey for their comments during their visit to the excavation. The dendrochronological analyses are the work of the Archéolabs Laboratory (Le Châtelard, Saint-Bonnet-de-Chavagne, Isère).

\section{Bibliography}

Agricola, G. (1950). De re metallica, Translated from the first Latin edition of 1556 by H.T. Hoover and L.H.T. Hoover. Dover publications. New York.

Amouric, H. (1984). Moulins et meunerie en BasseProvence occidentale du moyen-âge à l'ère industrielle. Th. 3e cycle. Université de Provence. Aix-en-Provence.

Bailly-MaîTre, M.-C. (2000). Essai d'une mine de plomb et argent versus arenas en Oisans par ordre du gouverneur du Dauphiné, le 15 octobre 1359. In: A. Belmont (dir.). La Pierre et l'Ecrit, Pierres de mémoire, écrits d'histoire, Hommages à V. Chomel. PUG. Grenoble: 131-43.

Bailly-Maître, M.-C. (2002a). Concasser et broyer sur un site minier des XIIe-XIVe siècles : Brandes-en Oisans (Huez, Isère). Première étude à partir des outils, des ateliers et des résidus. In: H. Procopiou aND R. TReUIL (eds). Moudre et broyer. L'interprétation fonctionnelle de l'outillage de mouture et de broyage dans la Préhistoire et l'Antiquité : II - Archéologie et histoire : du Paléolithique au Moyen-âge. Paris: 213-28. 
Bailly-Maître, M.-C. (2002b). L'argent : du minerai au pouvoir dans la France médiévale. Picard. Paris. Bailly-Maître, M.-C. AND Dupraz, J. (1994). Brandesen-Oisans : la mine d'argent des Dauphins, XII-XIVe s.: Isère. Lyon.

Bailly-Maître, M.-C., Gigante, A. and Warin, I. (2009). Brandes-en-Oisans, Programme 25, Rapport 2009, SRA Rhône-Alpes, Lyon, vol. 2, Pl. II-31 et 32. Unpublished site report.

Bailly-Maître, M.-C. and Minvielle Larousse, N. (2011). Brandes-en-Oisans, Programme 25, Rapport de fouille 2011, SRA Rhône-Alpes. Lyon: 71-99.

Bailly-Maître, M.-C. and Minvielle Larousse, N. (2014). Brandes-en-Oisans, Programme 25, Rapport de fouille final 2012-2014, SRA Rhône-Alpes, Lyon, 2 vol. Unpublished site report.

Belmon, J. (2003). La production de l'argent en Rouergue au Moyen Âge : première approche d'après les sources écrites. In: Rouergue, carrefour d'histoire et de nature. Actes du 54 e congrès de la Fédération Historique de Midi-Pyrénées. Rodez: Fédération Historique de Midi-Pyrénées. Société des lettres, sciences et arts de l'Aveyron: 238-72.

Benoît, P. (1997). La mine de Pampailly XVe-XVIIIe siècles (Brussieux Rhône). Service régional de l'archéologie de Rhône-Alpes. Lyon.

BEnoît, P. (2014). Remarques sur les fouilles de moulins à eau médiévaux en Europe, 32.

BENô̂T P. (2016). Remarques sur les fouilles de moulins à eau médiévaux en Europe. In: L. JAcCotTEY AND G. Rollier (dirs.). Archéologie des moulins hydrauliques, à traction animale et à vent des origines à l'époque médiévale et moderne en Europe et dans le monde méditerranéen. Presses Universitaires de FrancheComté. Besançon: 51-75.

Benoît, P., Bailly-Maître, M.-C., Dubois, C. AND Serres, G. (1996). Meules rotatives médiévales pour le broyage des minerais. Techniques et économie antiques et médiévales: 62-69.

BLoch, M. (1935). Avènement et conquête du moulin à eau. Annales d'histoire économique et sociale, VII: 538-63.

Braudel, F. (1993). Civilisation, économie et capitalisme: XVe-XVIIIe siècle. Tome 1, Les structures du quotidien : le possible et l'impossible. Librairie générale française. Paris.

Brun, J.-P. AND BorréAnI, M. (1998). Deux moulins hydrauliques du Haut-Empire romain en Narbonnaise: villae des Mesclans à La Crau et de Saint-Pierre/ Les Laurons aux Arcs (Var). Gallia, 55 (1): 279-326.

Comet, G. (1992). Le paysan et son outil: essai d'histoire technique des céréales. École française de Rome (ed.). Rome.
Dossat, Y. (1975). La mine d'argent d'Orzals en Rouergue pendant la seconde moitié du XIIIe siècle. In: Mines et métallurgie, XIIe-XVIe siècles: actes du 98e Congrès national des sociétés savantes, Saint-Étienne, 1973, Section de philologie et d'histoire jusqu'à 1610. Bibliothèque Nationale. Paris: 81-95. Available at: http://babordplus.univ-bordeaux.fr/notice. php?lang=es\&q=id:585449 [Accessed January 23, 2013].

Hrubý, P. (2011). Jihlava - Staré Hory. Archeologický výzkum středověkého dỉlního, úpravnického a obytného areálu v letech 2002-2006. Univerzita Karlova v Praze. Prague.

JACKMAN, N. (2013). The mill at Kilbegly: an archaeological investigation on the route of the M6 Ballinasloe to Athlone national road scheme. The National Roads Authority.

KuRDNÁČ, J. (1992). Recherches archéologiques sur la production d'or en Bohême. In: Les techniques minières de l'Antiquité au XVIIIe siècle. Actes du Congrès national des sociétés savantes. Section d'histoire des sciences et des techniques. Éd. du CTHS. Paris: 299-313.

Minvielle Larousse, N. (2009). La meunerie delphinale en Grésivaudan à la fin du Moyen Âge. Mémoire de Master I d'histoire, Université Pierre Mendès France, Grenoble II. Grenoble.

Minvielle LaRousse N. (in press). Les meules du moulin à minerai médiéval de Brandes-en-Oisans. In: O. Buschenschutz, G. Fronteau and S. LepareuXCouturier (dirs.). Les meules à grain du Néolithique à l'an mille : technique, culture, diffusion. Revue archéologique de l'Est.

Minvielle Larousse, N. and Bailly-Maître, M.-C. (2011a). Eléments de méthodologie pour l'étude de meules et moulins à minerai médiévaux. In: O. Buschenschutz, L. Jaccottey and J.-L. Blanchard (eds). Evolution typologique et technique des meules du néolithique à l'An Mille. Aquitania. Bordeaux: 469-79.

Minvielle Larousse, N. and Bailly-Maître, M.-C. (2011b). Ore grinding in the Middle Ages: the example of Brandes-en-Oisans (Isère, France). In: D. Williams and D. Peacock (eds). Bread for the people: The Archaeology of Mills and Milling. University of Southampton, Series in Archaeology, Archaeopress. Oxford: 217-30.

Mugueta Moreno, I. (2004). Política monetaria en Navarra bajo el reinado de los primeros Evreux. En la España Medieval, 27: 77-104.

Pulou, R. B. Jarrier, D. Béziat, Claude Domergue, J.G. Morasz, Béatrice Cauuet, Christian Landes, P. Oliva, F. Tollon (1997). Les moulins rotatifs dans les mines et les centres métallurgiques antiques. In: Techniques et économie antiques et médiévales : le temps de l'innovation. CNRS. Aix-en-Provence: 48-61. Available at: http://dialnet.unirioja.es/servlet/ articulo?codigo=2057190 [Accessed February 12, 2014]. 